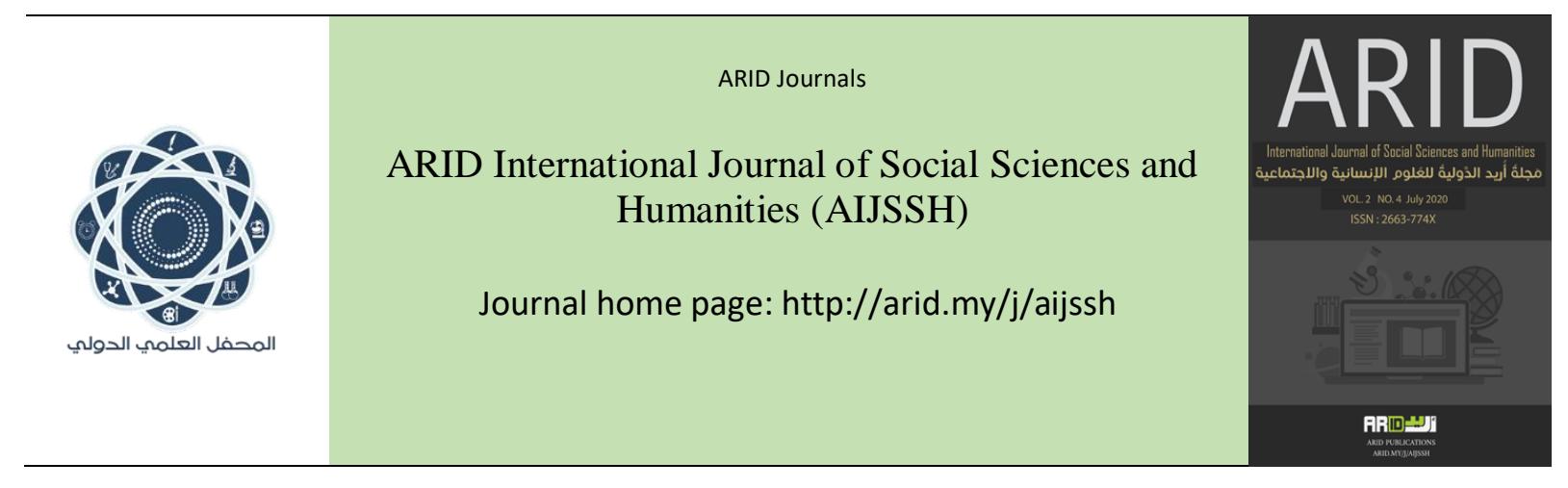

$$
\begin{aligned}
& \text { مَجلةُ أُريد الدَّوليةُ للعُلورج الإنسانية والإجتماعية } \\
& \text { المجلد الثاني ،العدد الرابع ، تموز } 2020 \text { م }
\end{aligned}
$$

\title{
A proposed vision for developing the professional performance of educational leaders in the Kingdom of Saudi Arabia in the light of the Vision 2030
}

\author{
Mastora Abd Alla Garad El Zahrany
}

General Education Department of Education Jeddah, Kingdom of Saudi Arabia

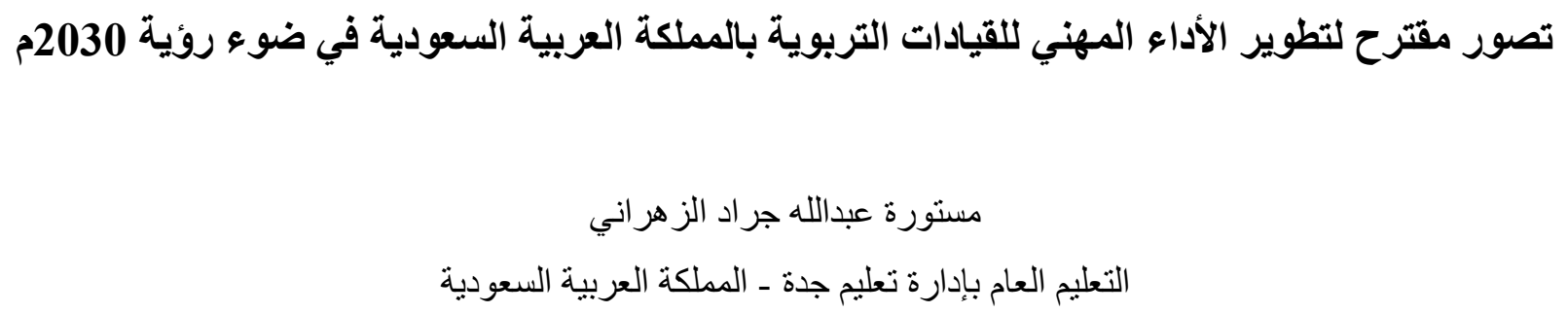

ms1400@hotmail.com

arid.my/0004-1537

https://doi.org/10.36772/arid.aijssh.2020.248 


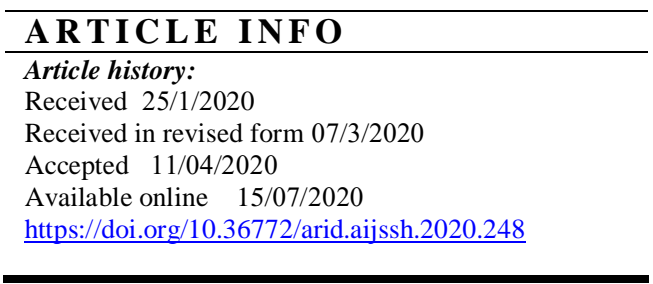

\begin{abstract}
The study aimed to identify the reality of the professional performance of educational leaders in the Kingdom of Saudi Arabia, and to identify obstacles to the professional performance of educational leaders in the Kingdom of Saudi Arabia. The study also aimed to determine the requirements for developing the professional performance of educational leaders in the KSA in light of the 2030 vision. The study used the descriptive and analytical method due to its relevance to the nature of the study, and it revealed several results, the most important of which are: The reality of the professional performance of educational leaders in the Kingdom of Saudi Arabia came to a high degree; Because of the existence of clear criteria for evaluating the professional performance of educational leaders, and the contribution of professional development programs in raising the efficiency of educational leaders in decision-making, and the results of the study showed that obstacles to the professional performance of educational leaders in the Kingdom of Saudi Arabia are scarcity of an integrated information base for the training needs of educational leaders, and the weak commitment of training centers To implement professional development programs according to the set plan, The weak interest of education departments in implementing the annual plan for the professional development of educational leaders, the weakness of the evaluation plans for professional development programs presented to educational leaders, and the absence of indicators indicating the achievement of the goals of the professional development plan for educational leaders. The results of the study also showed that the requirements for developing the professional performance of educational leaders in the Kingdom of Saudi Arabia are Establishing a specific plan for the professional development of educational leaders in line with the Kingdom's vision 2030 AD, and the availability of indicators indicating the achievement of the goals of the professional development plan for educational leaders that are compatible with the goals of the Kingdom's 2030 vision. With the vision of the Kingdom 2030 AD, With the necessity of the availability of indicators indicating the achievement of the objectives of this plan and the extent of its compatibility with the goals of the Kingdom's Vision $2030 \mathrm{AD}$, and the formulation of a professional development plan for educational leaders based on the actual training needs.
\end{abstract}




\section{الملخص}

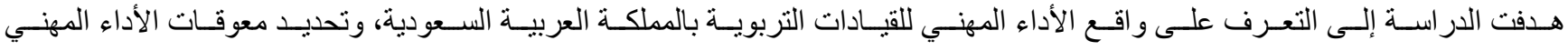

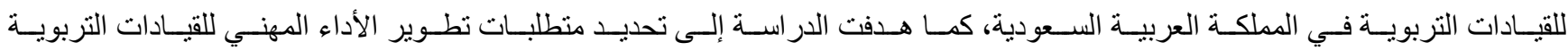

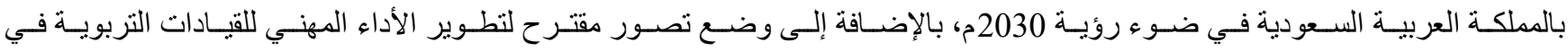

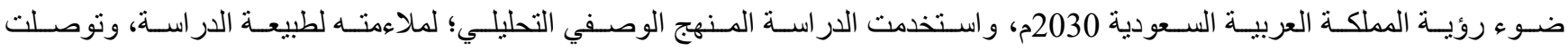
الدر اسـة إلـى عدة نتـائج مـن أهمها: أن و اقـع الأداء المهنـي للقبـادات التربويـة بالمملكـة العربيـة السـعودية جـاء بدرجـة عاليـة؛ لوجـود معـايير

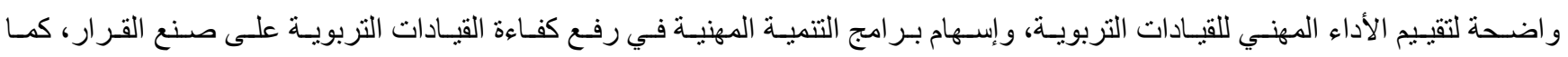
بينــت نتـائج الدر اســة أن معوقـات الأداء المهنـي للقبـادات التربويـة فـي المملكـة العربيـة السـعودية نــدرة وجـود قاعـدة معلومـات متكاملــة

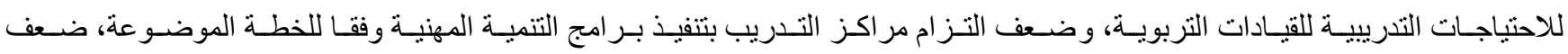

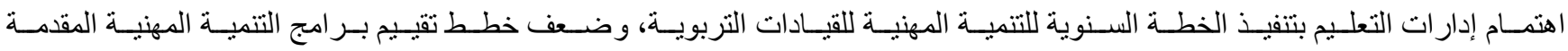

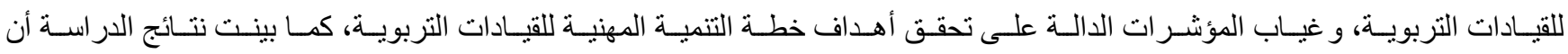

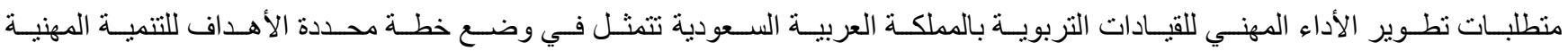

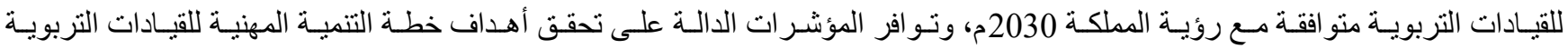

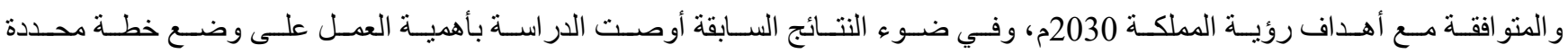
الأهـداف للتنميـة المهنيـة للقيـادات التربويـة متو افقـة مـع رؤيــة المملكـة 2030م، مـع ضـرورة تـو افر المؤشـر ات الدالـة على تحقـق أهـداف

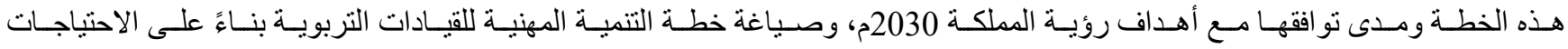
التدرييية الفعلية.

الكلمات المفتاحية: تصور مقترح، الأداء المهني، القيادات التربوية، رؤية المملكة 2030م 
الإطار العام للاراسة:

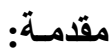

أصـبح التركيـز على الأداء المهنـي للمـورد البثـري ســـة بـارزة لـدى الكثيــر مـن المؤسسـات التعليميـة لتلبيـة احتياجـات

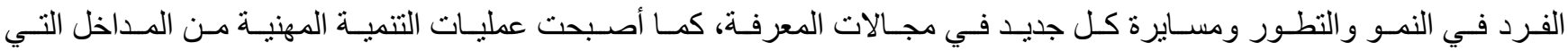

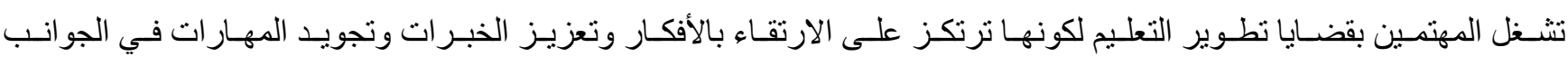
المعرفية و المهارية و الوجدانية لمو اجهة تلك التحديات.

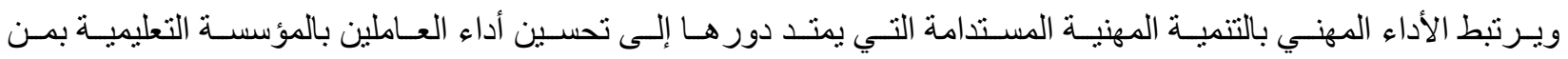

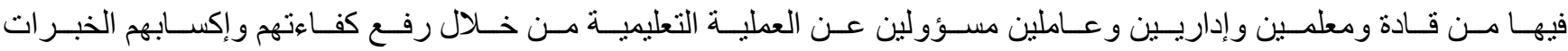
و المهار ات اللازمة لتطوير أدائهم إلى الأفضل. [1]

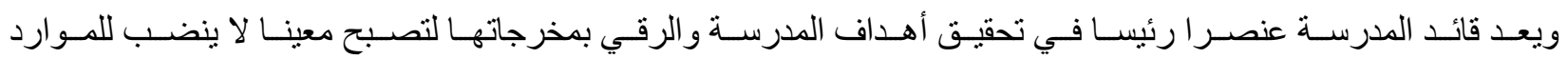

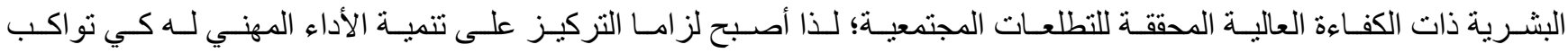
احتياجاته واحتياجات الميدان التربوي الفحلية و المتجددة لخلق كو ادر قيادية مدرسية تو اكب تطلعات المستقبل. [2]

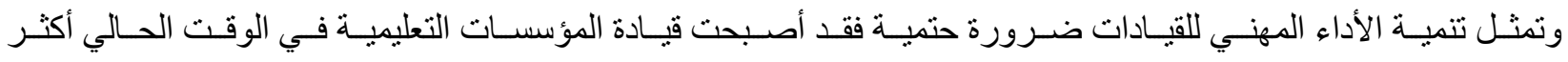

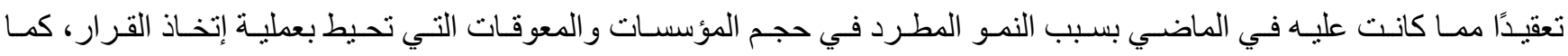

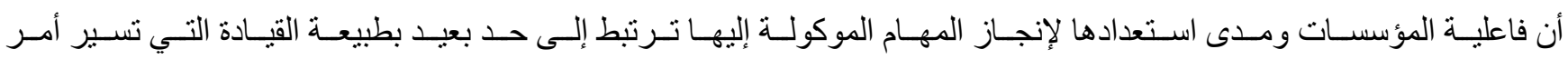
[3] [3ؤسسة وتعمل على تحقيق أهدافها.

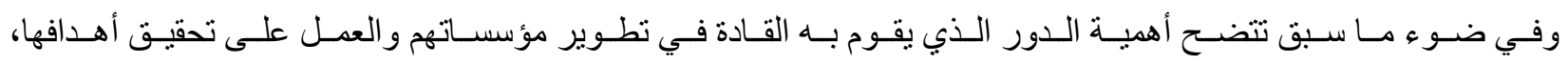

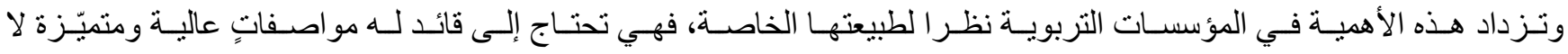

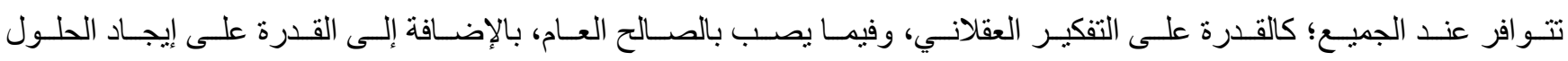
الإبداعيّة لكافّة المشاكل التي تو اجهه المؤسسة التعليمية.

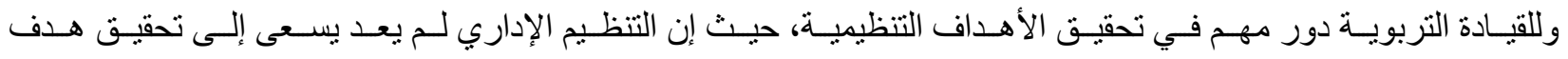

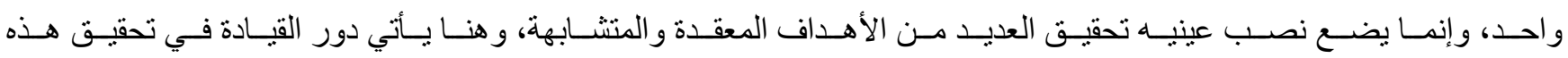
الأهـداف مـن خـلال توضـيحها وتحديـدها بـين تبـاين المو اقـف وبـين إثـباع الحاجـات، ومتطلبـات التنظيمه، وقـدرة القيـادة على 


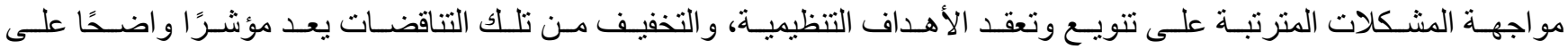
[4] [نجاح القيادة وفعاليتها

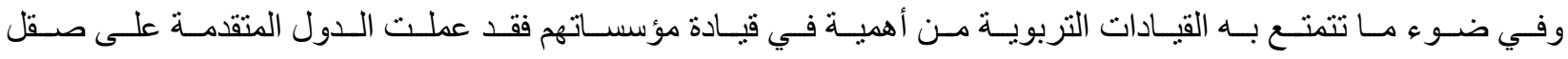

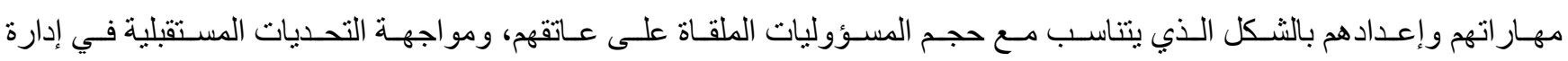
مؤسساتهم، وذللك من خلال إلحاقهم بالعديد من بر امج التنمية المهنية.

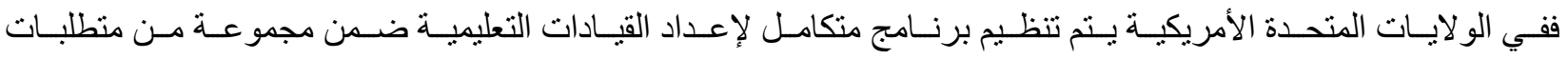

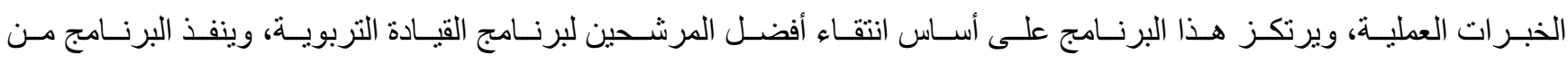

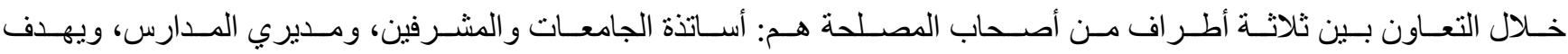

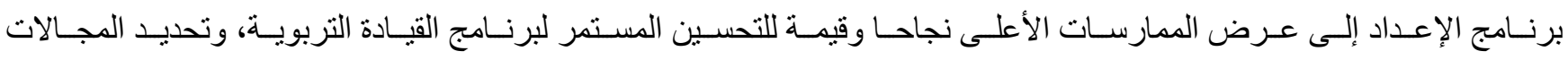
العمليـة التـي تلبـي المطالب التعليميـة للمرشـحين للبرنـامج، مـع تسـليط الضـو ء على المجـالات العمليـة التـي تحتــاج إلى تحسـين.

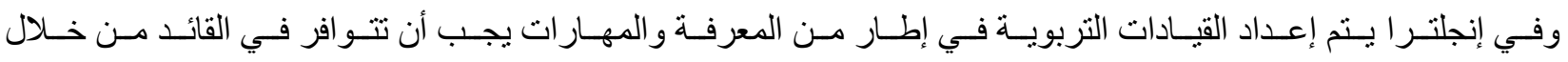

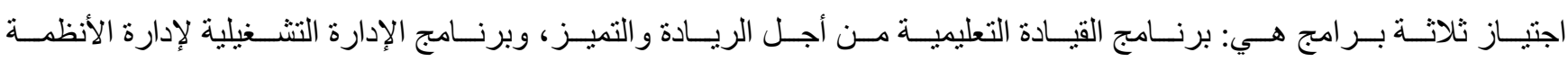

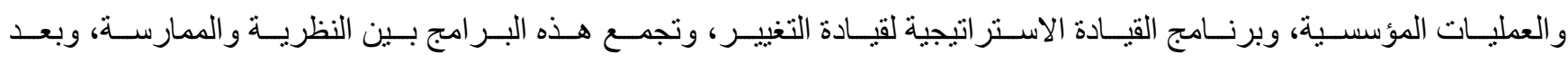

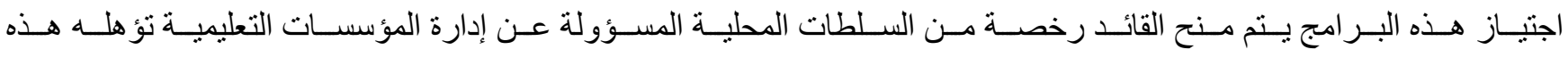
[6] الرخصة لقيادة المؤسسات التعليمية. و إدر اكـا مـن الحكومــة الأسـتر الية لأهميـة إعـداد القيـادات قامـت بـالترويج على نطـاق واسـع لأهميـة القيـادة فـي تحسـين النتـائج التعليميـة فـي المــارس، ووضـعت مجموعـة مـن الممارسـات النموذجيـة للقيـادة بـدلا مـن التركيـز علـى شـخص القائـد أو الصـفات القياديـة، و اهتمـت بتـدريبهم علـى ممارسـات القيـادة مـن خـلال مجموعـة متنو عــة مـن الأدوار و التصـرفات وفقـا لنظريــة الممارسـة الحديثـة التـي تسـتجيب للمشـكلات المؤسسـية بفاعليـة، مـع تسـليط الضـو و علـى الممارسـات التـي أثنتــت نجاحهـا في [7] [الميدان التربوي.

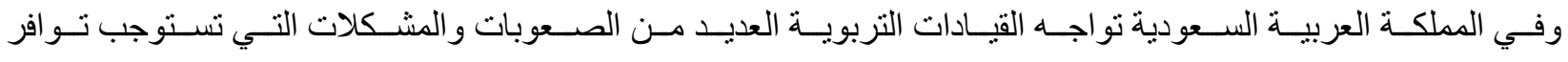
بـر امج تتميـة مهنيـة عاليـة الكفــاءة لتطـوير مهـار ات القـادة وقـدر اتهم علـى مواجهـة هـذه الصـعوبات و المشـكلات التـي تــواجهمه 


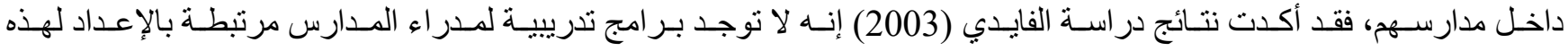
الوظيفة و الاكتفاء بالبر امج التقليدية، كما لا توجد فلسفة وأهداف محددة لتدريب مديري المدارس على متطلبات وظائفه.

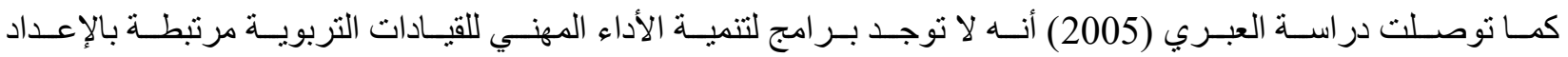
للوظيفـة الحاليـة وأن محسور أسـاليب التنميـة المهنيـة هـو الأكثـر سـلبية مـن حيـث تتـوع أسـاليب التنميـة المهنيـة كبـر امج عامـة،

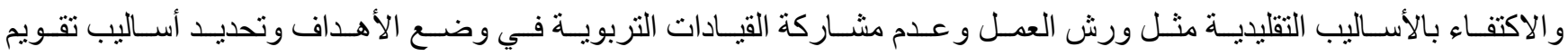
بر امج التنمية المهنية وضعف ارتباط محتوى البرامج بالأهداف الموضو عة.

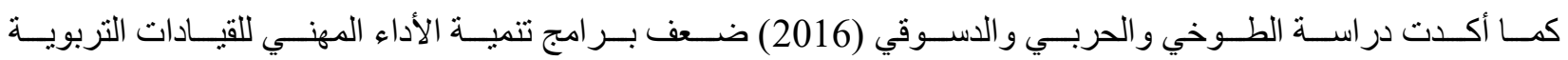
بالمملكـة و عـدم مر اعاتهـا للاحتياجـات التدريبيـة الفعليـة للقيـادات التربويـة وأن هـذا الثـيء يـؤثر على نفسـية وفاعليـة أداء هـــه القيادات الأمر الذي يستلزم تطوير بر امج التنمية المهنية المقدمة لهم. وقـــ هـدفت الرؤيسة الجديـدة للنظــام التعليمسي فـي المملكـة العربيـة السـعودية إلـى الارتقــاء بالمؤسســات التعليميـة، كـي تكـون ملائمـة لمتطلبـات الحيـاة فـي القـرن الحـادي و العشـرين، وتتـوفر فـي القـائمين عليهــا المهـار ات القياديـة التـي تمكـنهم مـن

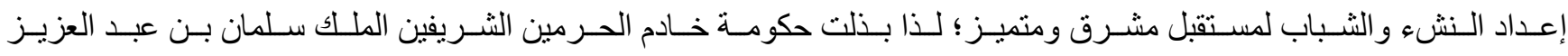
جهـودا جبـارة، مـن أجـل إعـداد شــاغلي الوظـائف القياديـة و امـتلاكهم الخصــائص والمهــار ات التـي تمكـنهم مـن القيـام بمهـامهر ومسؤولياتهم وممارستها بفاعلية، من خلال تدريبهم أثناء الخدمة على العديد من أنشطة وبر امج التنمية المهنية.[8]

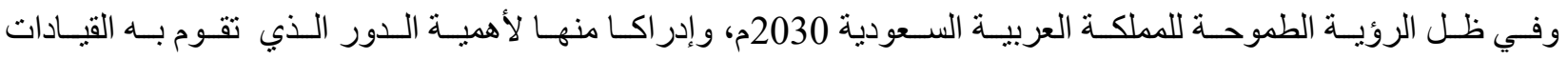

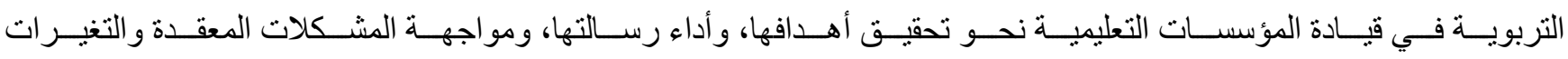
المتسـار عة التـي تحبط بهـا، فـإن ذلك يتطلب وجـود خطـة متكاملـة الأركان لتنميـة القيـادات التربويـة مهنيـا و إعدادها لأن تكون جاهزة لقيادة التغير وقادرة على تكييفه والتكيّف معه، قيادة واعيـة لديها القدرة على التفكير والتنظيم والقدرة على إدارة المعرفة المتدفقة بشكلها السريع، وتمكين جيع العاملين منها، وهذا لن يتأتى إلا عن طريق قيادة قادرة على التعامل مـع كل هذه المتغيرات ليس بشكل فردي، بل عن طريق العمل الجماعي والثقة المنبادلة بين القائد والعاملين معه، بما يخدم تحقيق أهداف رؤية 2030م. 
تو اجـه المؤسسـات التعليميـة فـي المملكـة العربيـة السـعودية تحـديات شـديدة نتيجـة للتغيـرات التكنولوجيـة السـريعة، الأمـر

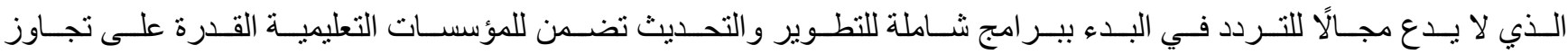
مشاكلها ونقاط الضعف فيها لتتو ائم مع متطلبات مجتمع المعرفة.

وقـد تز ايـدت الحاجـة في المملكـة إلـى تطـوير المؤسسـات التعليميـة أكثر مـن أي وقت مضـى ولـن يـتم ذلـك إلا مـن خـلال

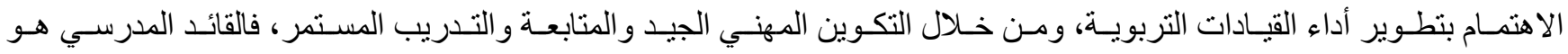
المحرك الأساسي و الفاعل في تحقيق جودة العملية التعليمية.[9]

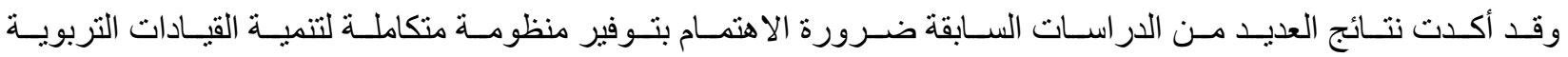

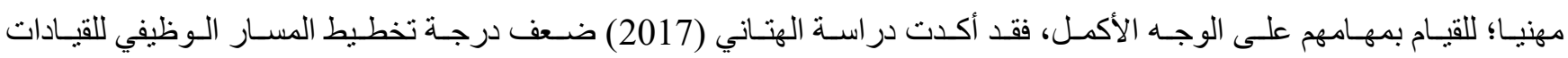
التربويـة علـى المسـتوى التنظيمسي، وضـرورة تبنــي إدار ات مكاتـب التعلـيم لاسـتراتيجيات تدريبيـة حديثـة لتنميـة الكفــاءة المهنيـة للقيادات المدرسية، وتوفير بيئة محفزة للقيادات للإبداع في عمله.

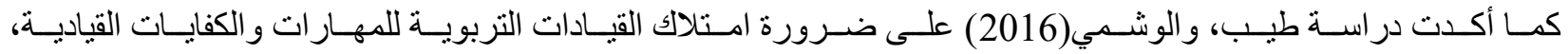
وكـذلك ضـرورة تــدريب القيـادات التربويـة أثنــاء الخدمـة لتنميـة ممار سـتهم للمهـار ات القياديـة والاسـتفادة مـن التوجهـات الحديثـة

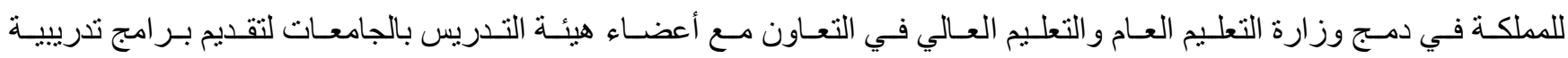
للقيادات التربوية في ممارسة المهار ات القيادية.

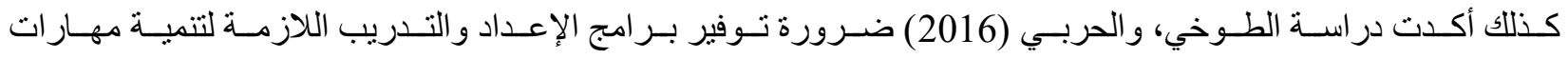
القيـادات التربويــة مهنيـا، وتـوفير التـدريب المسـتمر، وفـرص النـــو المهنـي، والعمـل علـى رفـع مسـتوى وكفــاءة القيـادات التربوية الفنية و الإدارية، وتكوين الخبرة العملية.

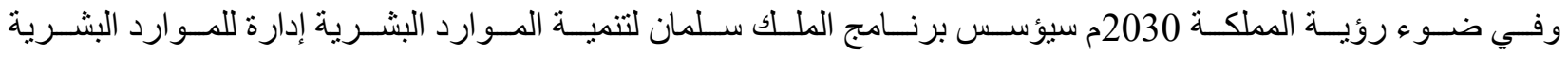

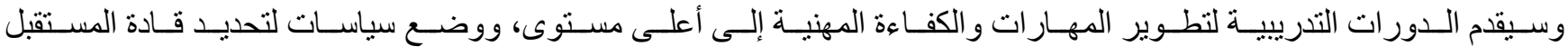
وتمكيـنهم مـن خـلال تعزيـز فـرص التـدريب والتأهيـل، وهـو مـا ينطبـق أيضــا على القيـادات التربويـة فـي المؤسسـات التعليميــة $[10]$. وتتجــه المملكـة العربيـة السـعودية مثــل معظـم المجتمعـات المعاصـرة إلـى القيــادات التربويـة باعتبـار هم مـن أهـم الأدوات

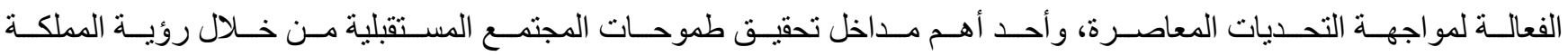




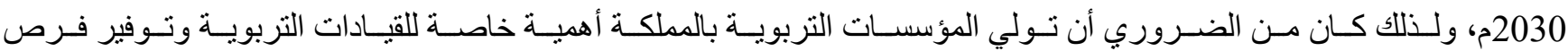

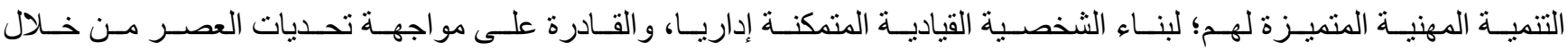
تزويدها بالمهار ات القيادية اللازمة.

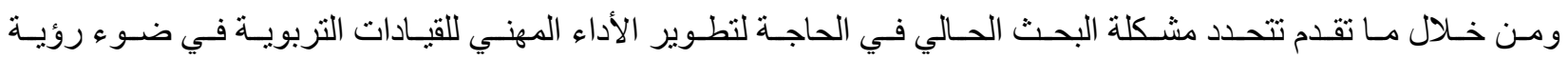

$$
\text { المملكة العربية السعودية 2030م. }
$$

تساؤلات الدراسة:

$$
\text { تتبلور مشكلة الدراسة في التساؤلات التالية: }
$$

$$
\text { 1. ما واقع الأداء المهني للقيادات التربوية بالمملكة العربية السعودية؟ }
$$

2. ما معوقات تطوير الأداء المهني للقيادات التربوية في المملكة العربية السعودية؟

3. ما متطلبات تطوير الأداء المهني للقيادات التربوية بالمملكة العربية السعودية في ضوء روئية 2030م؟ 4. ما التصور مقترح لتطوير الأداء المهني للقيادات التربوية في ضوء رؤية المملكة العربية السعودية 2030م؟

1. التعرف على و اقع الأداء المهني للقيادات التربوية بالمملكة العربية السعودية.

$$
\text { 2. تحديد معوقات الأداء المهني للقيادات التربوية في المملكة العربية السعودية. }
$$

3. تحديد متطلبات تطوير الأداء المهني للقيادات التربوية بالمملكة العربية السعودية في ضوء رؤية 2030م. 4. وضع تصور مقترح لتطوير الأداء المهني للقيادات التربوية في ضوء رؤية المملكة العربية السعودية 2030م.

تتشكل أهمية الدر اسة في جانبين رئيسين هما: الأهمية النظرية، و الأهمية التطبيقية:

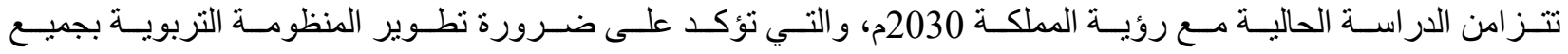
مكوناتهـا، وتأهيـل وبنـاء شخصـيات قياديـة قـادرة على الإسـهام الفعـال في تحقيق أهداف هـذه الرؤيـة، كمـا تتمثنل أهميـة الدر اســة

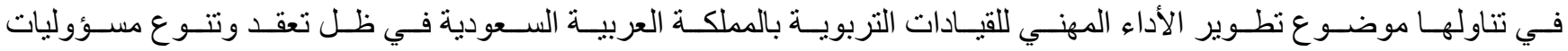

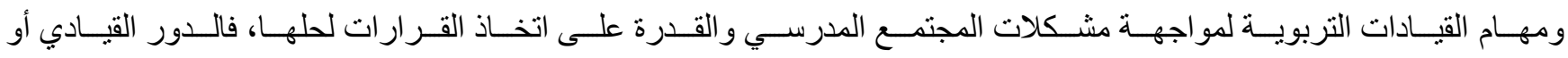
الأسلوب الذي يمارسه القائد التربوي يسهم بشكل كبير في مستوى أداء المعلمين. 
ثانيًا: الأهمية التطبيقية:

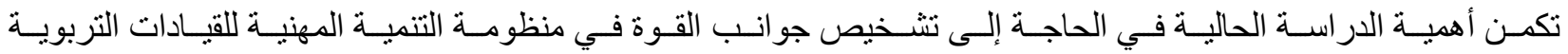

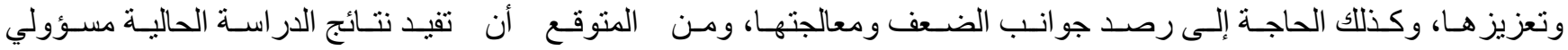

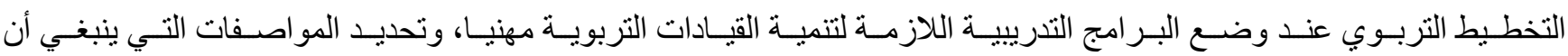
يتحلى بها القائد، وبخاصة في ضوء الرؤية الطموحة للمملكة 2030م. مصطلحات الار استة:

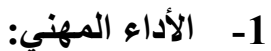
يعـرف الأداء المهنـي بأنـه " مجمو عـة مـن الأهـداف التـي تتـرجم فـي وسـائل وأنشـطة والتـي تتخــها المؤسسـة لتخطـبط و تطـو ير مسـتقبل الوظـائف لـديها مـن خـلال رفـع الكفـاءة و الكفايـة المسـتمرة للعـاملين بهـا لتلبيـة الاحتياجـات الحاليـة و المسـتقبلية للتطور الكمي و النوعي و التقني المستمر في الوظائف وفقًا لمعايير ومنطلبات الجودة العالمية". [11]

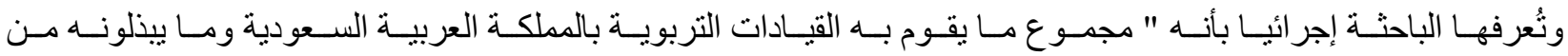

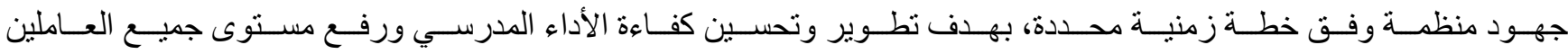
بالمدرسة، وتحسين العملية التعليمية، وذلك من خلال البر امج و الأنشطة التي تنفذ داخل وخارج المدرسة.

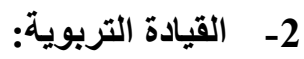

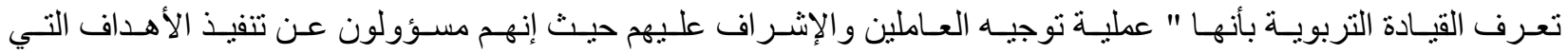
أرساها التخطيط، ويتحمل القائد التربوي مسؤولية توفير الدافعية للعاملين مهما كانت دقة الخطط أو كفاءة التنظيم". [12] وتُعرفها الباحثنة إجرائيا بأنها ذلك التفاعل الاجتمـاعي التربوي بين مدير المدرسة والجماعـة المدرسية (العمـال المدرسين - التلاميذــ المجتهع المحلي وأولياء الأمور) ومـا يتضـمنه هذا التفاعل من عمليات التأثير والاتصـال والتوجيـه، و اتخاذ القرارات وحل المشكلات، لغرض تحقيق الأهداف التربوية. 3-

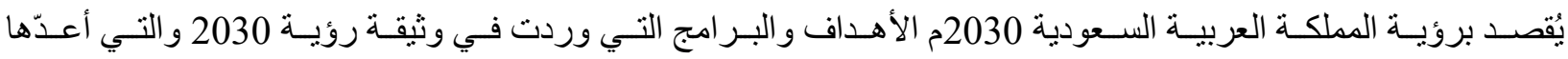
مجلـس الثـؤون الاقتصــادية و التنميـة فـي المملكـة العربيـة السـعودية وتعـرف بأنهـا "خارطـة طريـق نحـو الوصـول للأهـداف المر ادة، و البوصلة التي توجه جميع الأعمال نحوها". [13] 


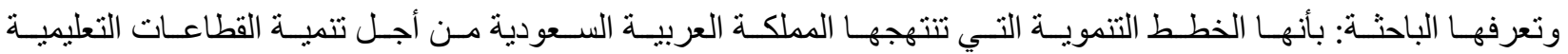
و الصـناعية و التجاريـة و الصـحية و الخـدمات المختلفـة مـن أجـل النهـوض بالدولـة، وقـد ركزت في بعض أجز ائهـا على ضـرورة بناء الثخصية القيادية المتفتحة. الإطار النظري للاراسة:

\section{أهداف تنمية الأداء المهني للقيادات التربوية:}

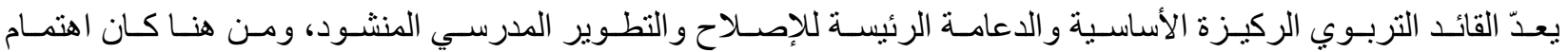
جـودة التعلـيم بتنميــة الأداء المهنـي للقيـادة التربويسة، فوضـعت بعـض المعـايير و الممارسـات التـي تسـهم فـي تفعيـل دور القائـد

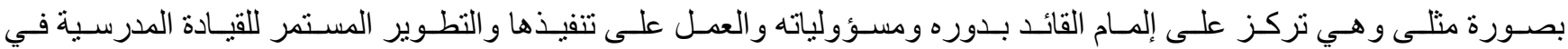
اسـتخدام التكنولوجيـا الحديثـة و مصــادر ها المختلفـة و الاسـتفادة مـن التخذيـة الر اجعـة التـي توجّهـه إليـهـهـ مـن قبـل الجهـات الخارجيـة أو الداخلية التي تتابع سير العملية التعليمية داخل المدرسة أو حتى من خلال تقييمه لنفسه و أدائه اليومي. [14] ولكـي تصـــح بتتميـة الأداء المهنـي للقيـادة التربويـة عمليـة اسـتثمار فعـال للمـوارد البشـرية يلـزم أن تتبـع أهـدافها مـن الاحتياجـات الفعليـة للقائـد، لتلافي أوجـه القصـور في إعداد القائـد قبـل التحاقـه بالمهنـة، ومسـاعدة القـادة الجـد في المهنـة لتيسـير

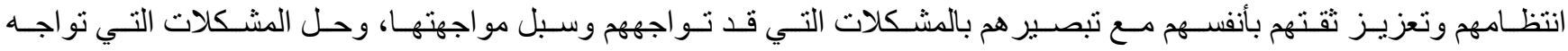
القـادة القـدامى و إطلاعهـم علـى أحـدث النظريــات الإداريــة والتربويـة و النفسـية وتقنيـات التعلـيم الحديثــة و اســتخدام الأسـاليب [15] الجديدة.

كمـا تهـدف عمليـة تتميـة الأداء المهنـي للقيـادة التربويـة إلى تخفيف بعض المعوقـات التي تو اجـه القـادة في عملهم وبنـاء بـر امج تتمويـة متكاملـة وفعالـة للقـادة تسـعى إلـى تنميـتهم داخـل المدرسـة، و تـــعيم دور الإدارة المدرسـية فـي تنميـة المعلمـين

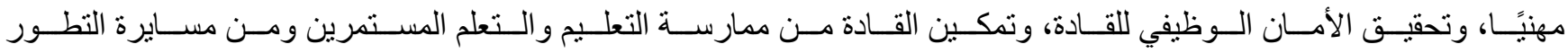
التكنولوجي والثورة المعرفية.[16]

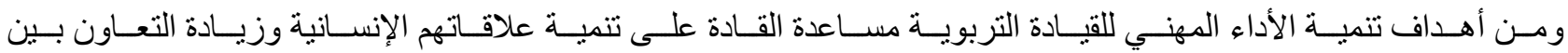

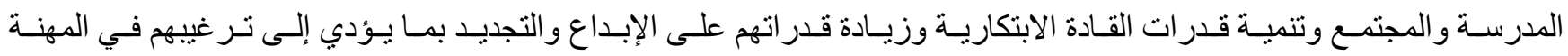

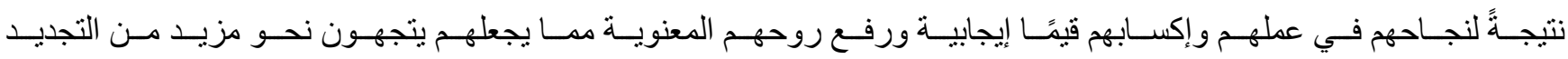
و 


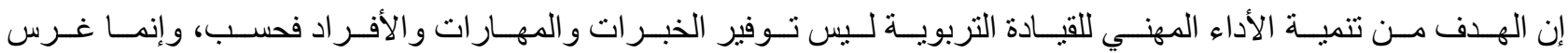

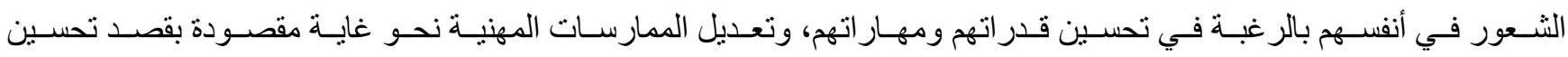

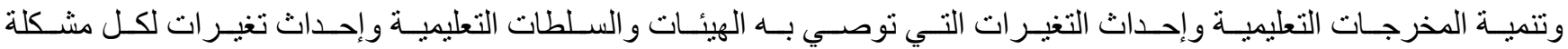
در اسـية يتطلـب حلهـا إجـر اء تعـديل في البـرامج التدريبيـة وهكذا يـؤدي النــو المهنـي دوره في مسـاعدة مـديري المـدارس على تنفيذ ذلك التعديل.

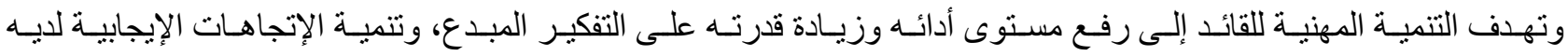

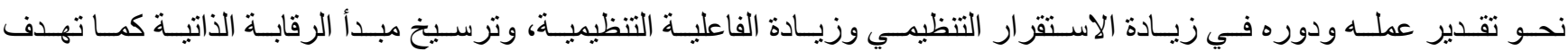
التنمية المهنية إلى النمو المهني للقائد شخصيًا وتطور قدر اته وكفايته الأكاديمية و السلوكية و العلمية والإدارية.[19]

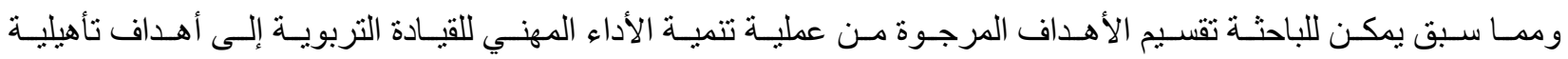

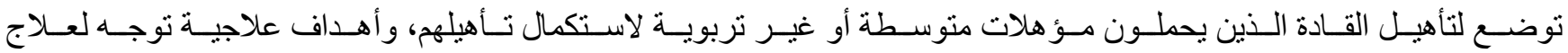

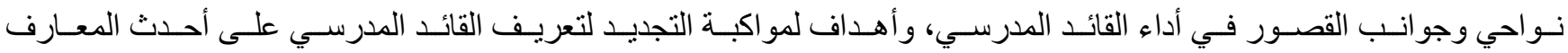

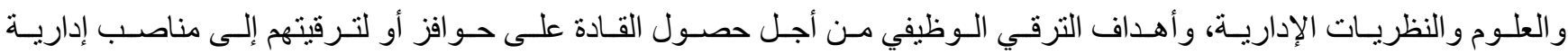

\section{مبررات تنمية الأداء المهني للقيادات التربوية:}

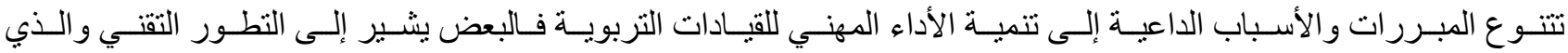

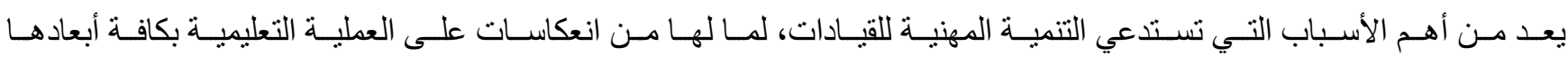
ومجالاتها، ومن خلال ذلك شعرت المؤسسات التعليمية بأهمية التنمية المهنية للقيادات نتيجة للمبرر ات التالية:[20] - - تستطيع القيادات من خلال عملية التنمية المهنية أداء أعمالها وو اجباتها بصورة أكثر فاعلية وجودة. - - - - إكساب القيادات مهار ات وقدر ات جديدة في مجال تخصصها. - إتاحة مجال مفتو ح لتعليم على مستوى عالي ولتعليم مدى الحياة. - المساعدة على فهم الثقافات الوطنية و الإقليمية وتفسير ها وتعزيز ها.

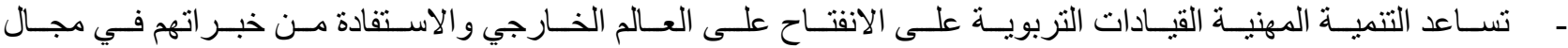
التعليم. - - التخلص من الأساليب التقليدية في القيادة و الإدارة و استبدالها بالأساليب الحديثة. 


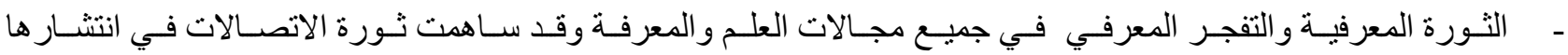
و اتساع نطاقها .

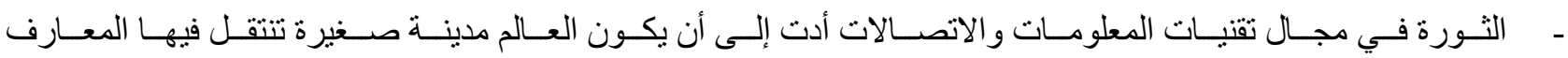
المستجدة بسرعة هائلة. - تعدد أدوار القيادات التربوية وتعدد مسؤلياته في المجال القيادي و الإداري. - المستجدات المتسار عة في مجال القيادة و الإدارة مما يتطلب من القائد مو اكبة ذلك. - التوجه العالمي نحو التقيد بالجودة الثاملة للعملية التعلمية و الاعتماد الأكاديمي مجال الإدارة. - مواكبة كل ما هو جديد ومنطور في العملية التعليمية وتطبيقه وفق المعايير الدولية.

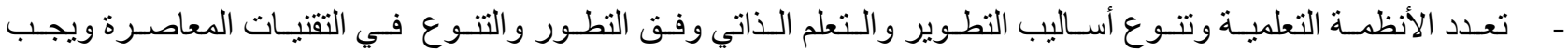
على المعلم مو اكبة ذللك.

الاراسات السابقة:

\section{المحور الأول: دراسات تناولت التنمية المهنية:}

قـام كثـكو (2017 ) بدر اســة هـدفت إلـى التعـرف على فاعليـة برنــامج مقتـرح ح للتنميــة المهنيـة قـائم على الـتعلم الـذاتي

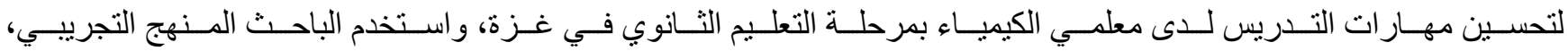

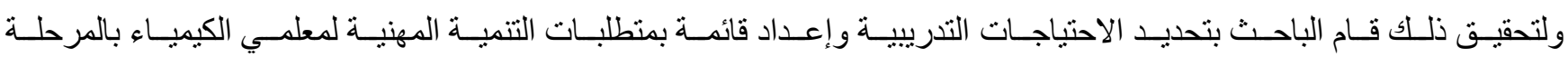

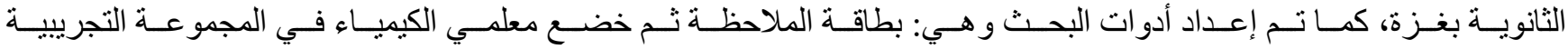

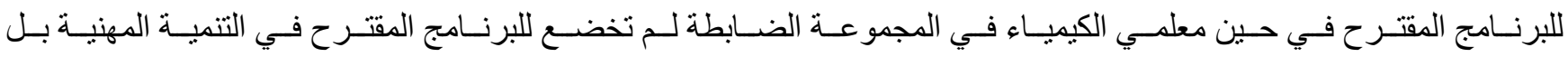

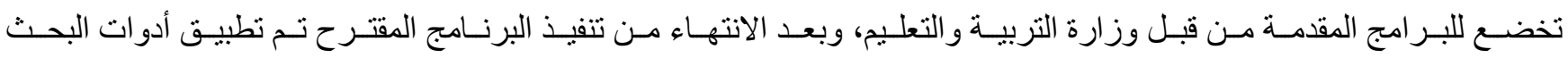
بعـديًا علـى نفـس مجموعـة البحـث (التجريبيـة و الضـابطة) مسن معلمـي الكيميـاء بمرحلـة التعلـيم الثـانوي بغـزة، وكثـفت نتـائج البحث فاعلية البرنامج المقترح في تنمية الجوانب المهارية لدى معلمي الكيمياء. كمـا قـام (Khuanwang, et al, 2016) بدر اسـة هـدفت إلـى تطـوير معـايير التقبيم و المؤشـرات الخاصـة بتقبيم

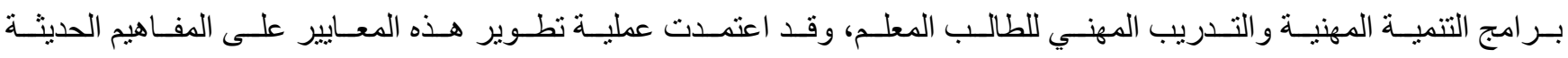
الخاصـة بتوجهـات التنميـة المهنيـة للمعلـم بالإضـافة إلـى النظريـات والدر اسـات و البحـوث التـي أجريـت في مجـال التنميـة المهنيـة 


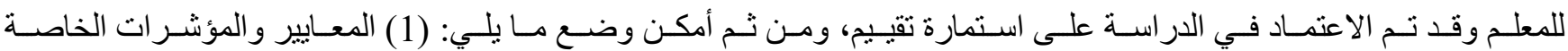
بيـر امج التنميـة المهنيـة للمعلمـين فـي تايلانـد، (2) المعـايير الدوليـة للتنميـة المهنيـة للمعلمـين 3) مهــار ات معلـم القـرن الحسادي

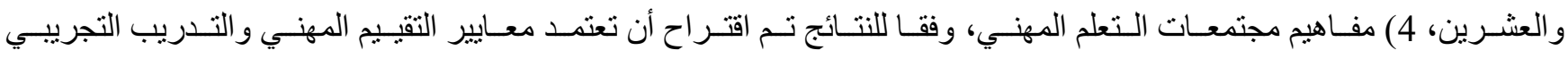
للطالبـات المعلمـات على ثـلات قواعـد هـي 1) كفـاءة التـدريس و البحـث في العمـل 2) التنميـة الذاتيـة للتقدم المهنـي، 3 )معـايير للتقييم سيستخدمها الطلاب و المدرسين المشرفين على المعلمين التدريب المهني التجريبي.

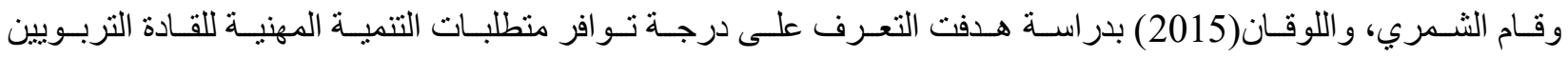
فـي المـدارس السـعودية، وكـذلك التعـرف على معوقـات التنميـة المهنيـة للقـادة التربـويين فـي المـدارس السـعودية، ودرجـة تحقـق

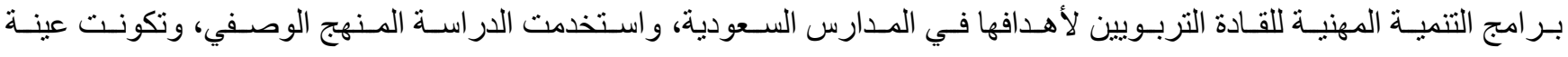
الدر اســة مـن (55) مـديرا، وتـم إعـداد اسـتبانة لجمـع البيانـات و المعلومـات، وتوصـلت الدراسـة إلـى أن درجـة تــوافر متطلبـات التنميـة المهنيـة للقـادة التربـويين فـي المــدارس الســودية جـاءت بدرجـة متوســة، وأن درجـة تحقيـق بـر امج التنميـة المهنيـة

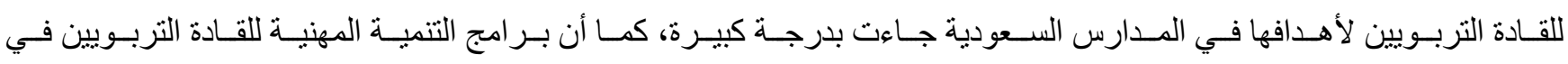
المدارس السعودية تو اجه العديد من المعوقات.

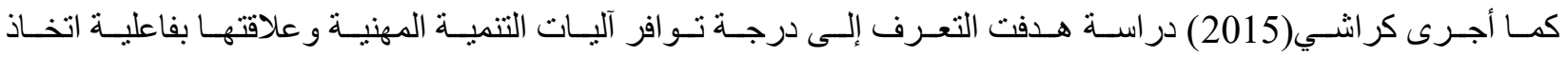

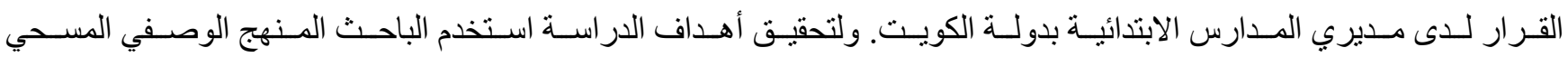

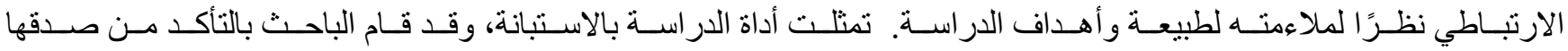
وثباتهـا وتكونــت عينـة الدر اســة مسن 346 مـديرًا ومسـاعديهم في جميـع المـدارس الابتدائيـة بدولـة الكويـت البـالغ عـددها 241 مدرسـة. توصـلت الدر اســة إلـى أن درجـة تــوافر آليـات التنميـة المهنيـة فـي المـدارس الابتدائيـة بدولـة الكويــت جـاءت بدرجـة عالية، وأن درجة فاعلية اتخاذ القرار لدى مديري المدارس الابتدائية في دولة الكويت جاءت عالية. و أجـرى (Sonia Bland ford, 2014) در اسـة هـدفت إلـى تعـرّف مفهـوم التنميـة المهنيـة للمعلـم، وأهـدافها، و أهميتهـا ومجالاتهـا. و الكثـف عـن دور المعلـم فـي تفعيـل العمليـة التعليميـة. و الوقـوف علـى الاتجاهـات العالميــة المعاصـرة فـي التنميـة المهنيـة للمعلمـين. اسـتخدمت الدر اسـة المـنهج الوصـفي بهـدف الخـروج برؤيـة مسـتقبلية مقترحـة يمكن أن تسـهم فـي

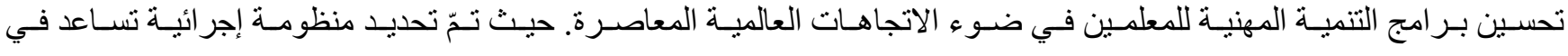
تحديـد وبلـورة اسـتر اتيجية وطنيـة لتطـوير بـر امج التنميـة المهنيـة للمعلمـين تتمثنل في: إقامـة مـؤتمر تربـوي دولـي يسـاعد في

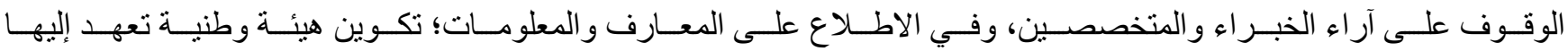




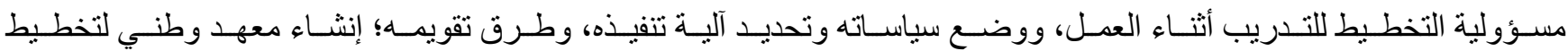
التعلـيم و التـدريب يهـتم بـالتخطيط و التطــوير و البرمجـة العلميـة المنطلقـة مـن الواقـع الاجتمــاعي، والاحتياجـات الفعليـة للمجتمـع و المعلم.

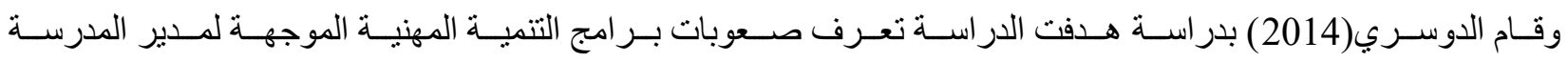
الثانويـة السـودية فـي السـياق التربـوي الـر اهن، وتعـرف أفضـل الممارسـات العالميـة المتبعـة فـي مجـال التنميـة المهنيـة لمـديري

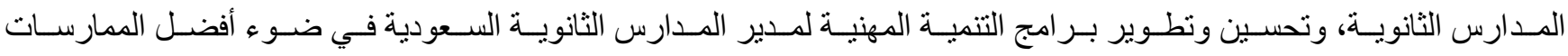

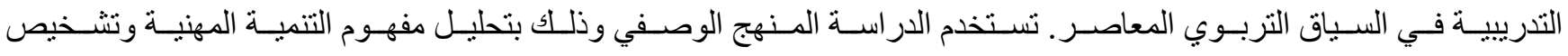

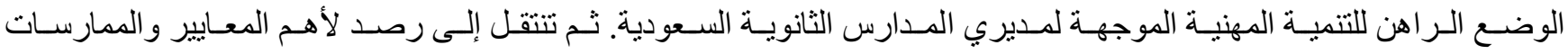

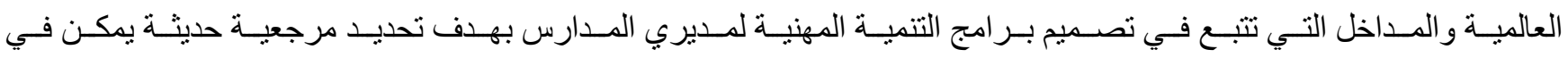
ضوئها تحسين بر امج التنمية المهنية الموجهة لمديري المدارس. المحور الثاني: دراسات تناولت القيادة التربوية:

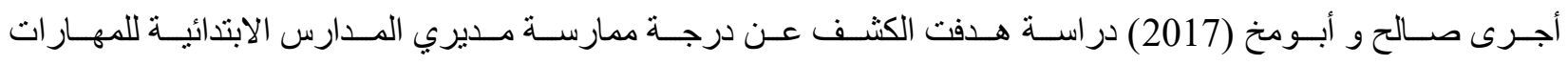
القياديـة مـن وجهــة نظـر المعلمـين داخـل الخـط الأخضـر في فلســين فـي ضـو ء المنظمـة المتعلمـة و الثقافـة التنظيميـة، ولتحقــق

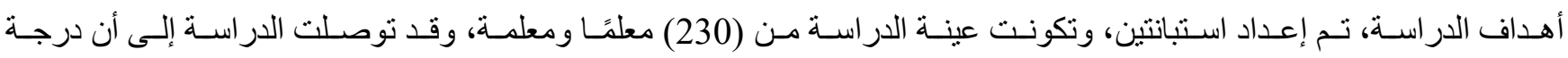
ممارسـة مـديري المــارس الابتدائيـة للمهـار ات القياديـة ككـل مـن وجهـة نظـر المعلمـين داخـل الخـط الأخضـر كانــ كبيـرة،

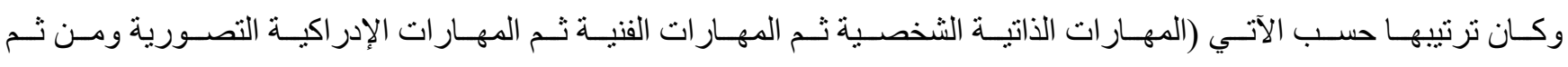

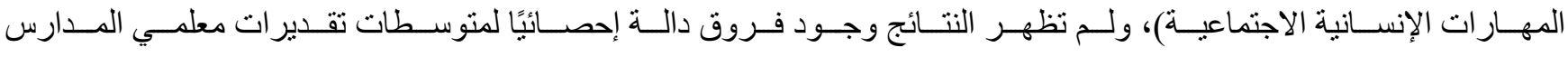

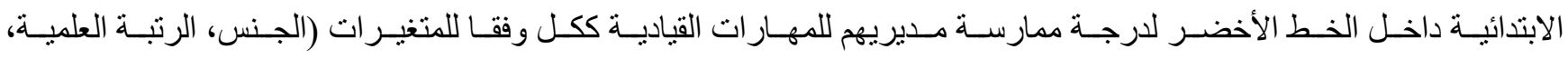
الخبرة، أعمل في مدرسة يدير ها/تدير ها).

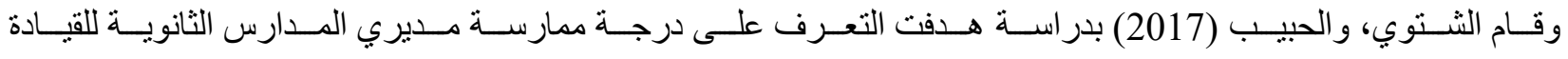

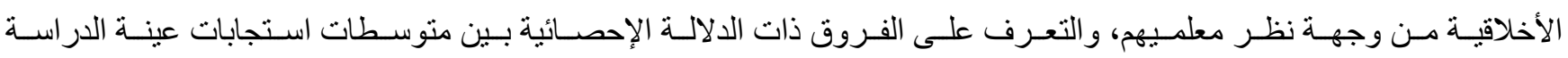

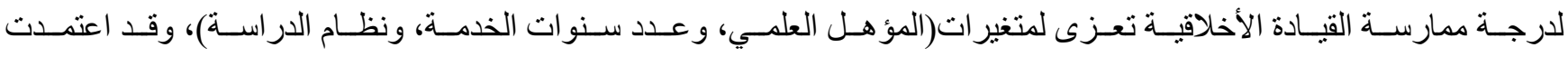
الدر اسـة علـى المـنهج الوصـفي المسـحي، واسـتخدمت الاسـتبانة أداة لهـا، طبقـت على عينــة عـددهم(367) معلمـا، وتوصـلت الدراسة إلى أن مديري المدارس الثانوية بمدينة الرياض يمارسون القيادة الأخلاقية بدرجة كبيرة. 
وقـام العنـزي(2016) بدر اســة هـدفت إلى تعـرّف الكفايـات القياديـة اللازمــة لمـدير المدرسـة فـي المرحلــة المنوســة فـي

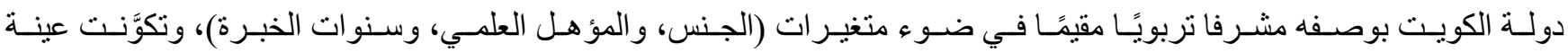

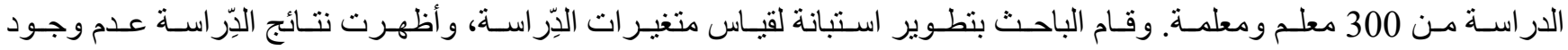
فـروق ذات دلالـة إحصـائية تعـزى لأثـر متغيـر الجنس فـي جميـع مجـالات ممارسـة مـدير المدرسـة في المرحلـة المتوســة في دولة الكويت للكفايات القيادية بوصفه مشرفًا تربويًا مقيمًا من وجهة نظر المعلمين. وقـام النعيمـات(2016) بدر اســة هـدفت لمعرفـة دور القيـادة المدرسـية فـي تتميـة الإبـداع لـدى معلمسي مـدارس المرحلــة الثنانويـة في تربيـة قصـبة عمـان ومـن وجهـة نظـر المعلمين، ومعرفـة الفروق بـين إفر اد العينـة حـول تتميـة الإبـداع لـدى المعلمين

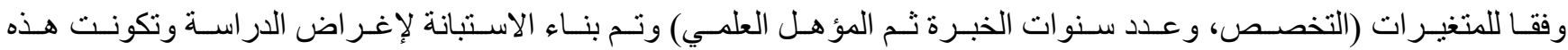
الدر اسـة مـن (27) حيـث اسـتخدم الباحـث المـنهج الوصـفي، وأظهـرت النتـائج جـاءت درجـة ممارسـة للقيـادة المدرسـية بدرجـة

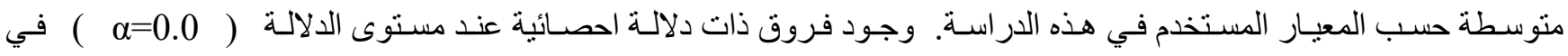
دور القيـادة المدرسـية في تتميـة الإبـداع لـدى معلمـي مـارس المرحلـة الثانويـة في تربيـة قصـبة عمـان مـن وجهـة نظـر المعلمـين تبعًا لاختلاف المؤ هل العلمي. كمــا قـام القحطـاني، والخـزي(2013) بدر اسـة هـدفت التعـرف واقـع اسـتخدام الهيئـة التعليميـة لتكنولوجيــا الاتصــالات و المعلومــات وتوظيفهـا، و اتجاهـاتهم نحـو إدارة التنميـة المهنيـة الـــي تقدمسه القيـادات الإداريـة المدرسـية لهـم بهـذا الخصـوص اعتمـدت الدر اسـة المـنـهج الوصـفي التحليلـي، باســخدام اسـتبانة طبقت على عينـة عشـو ائية قو امهــا 756 معلمـا، ودلـت النتـائج

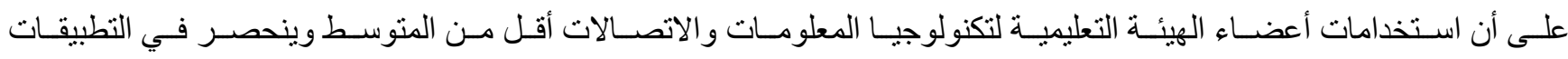
التقليدية، وأن تصور اتهم لدور القيادة الإدارية المدرسية نحو دعمه بهذا الخصوص ليس في مجمله إيجابيًا. وقـام الروقي(1433 هـ) بدر اسـة هـدفت إلى معرفـة الأنمـاط القياديـة السـائدة لـدى مـديري المـدارس الثانويـة بمدينـة مكـة المكر مـة مـن وجهــة نظـر المعلمسين، واسـتخدمت الدر اســة المـنهج الوصـفي الارتبـاطي، وتكونــت عينـة الدر اســة مـن 500 معلـم مـن جميـع معلمـي المرحلــة الثانويـة بالمـدارس الحكوميـة في مدينـة مكـة المكـة و اسـتخدم الباحـث اسـتبانة مـن إعـداده كـأداة للبحـث

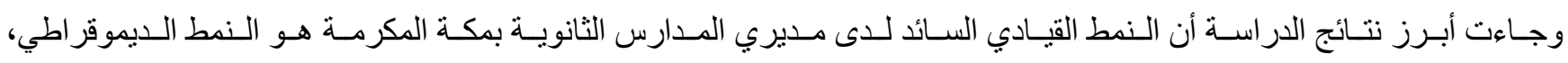

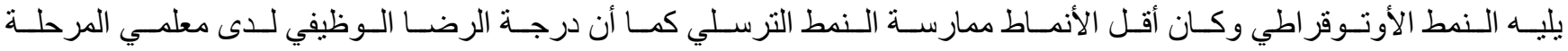
الثانوية من وجهة نظر هم كانت عالية. 


\section{المحور الثالث: دراسات تناولت التنمية المهنية وعلاقتها بالقيادات التربوية:}

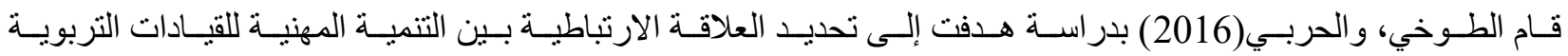

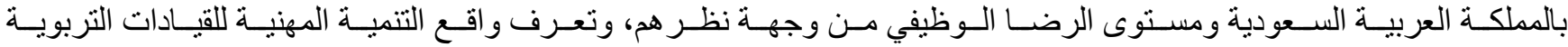

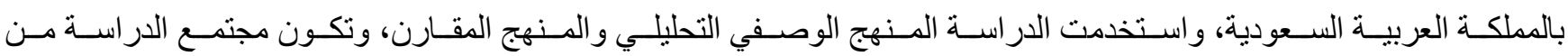
القيـادات الثربويـة فـي منطقـة القصـيم، واسـتخدمت الدراسـة الاسـتبانة أداة لهـا، وطبقـت علىى عينـة مسن 60 فـردا، وتوصـلت

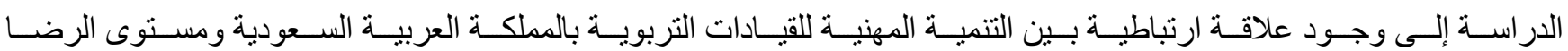
الوظيفي.

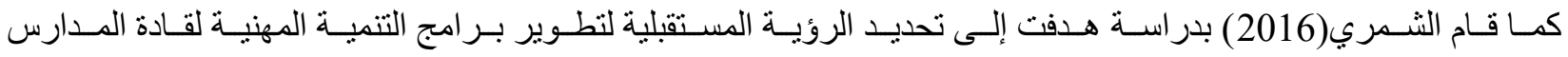
في مـدارس التعليم العـام بالمملكـة العربيـة السـعودية في ضـوء الاتجاهـات العالميـة، واسـتخذمت الدراسـة الـــهج الوصـفي مـن

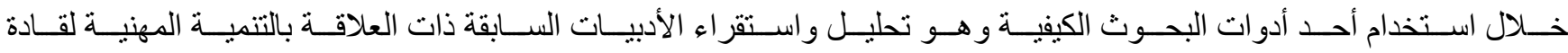

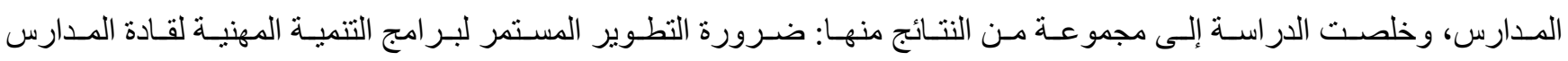

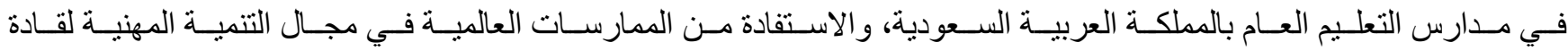
المدارس.

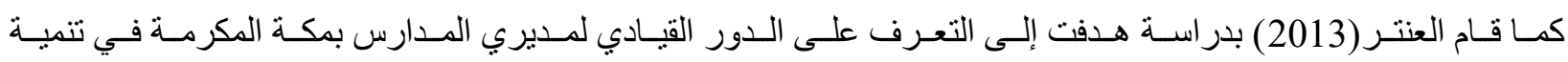

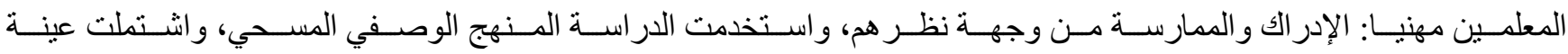

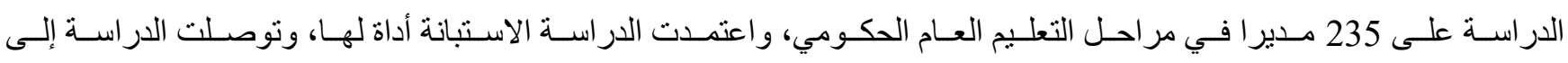

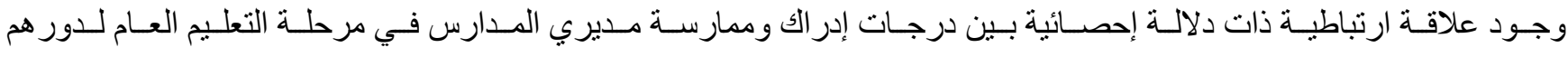
القيادي في تتمية المعلمين مهنيا اتجاه كل من محاور الدراسة.

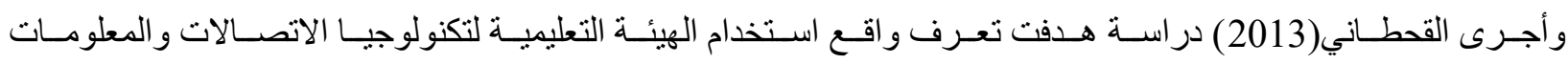

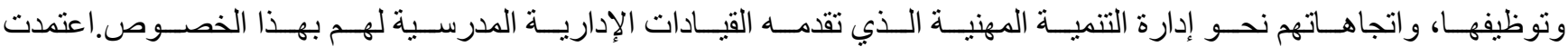

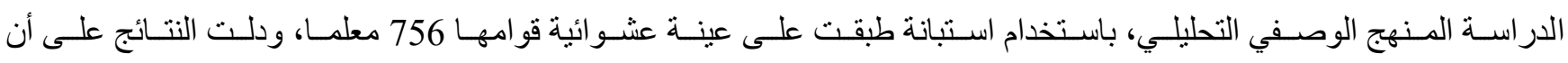

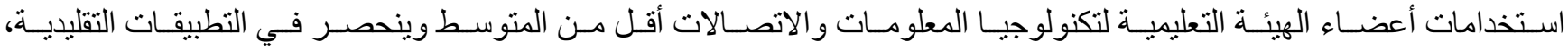
وأن تصور اتهم لدور القيادة الإدارية الددرسية نحو دعمهم بهذا الخصوص ليس في مجمله إيجاييًا. 
وقـام فـلاح (2012) بدر اســة هـدفت إلـى تعـرف مسـتوى الكفايـات المهنيـة لمـديري المـدارس الثانويـة الحكوميـة في دولــة

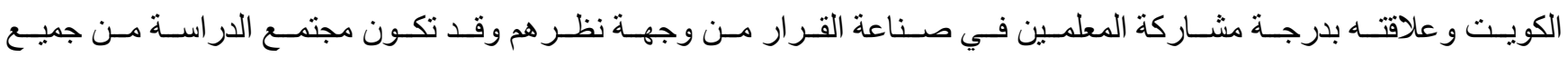
المعلمـين و المعلمــات فـي المـدارس الثانويـة الحكوميـة فـي جميـع المنـاطق التعليميـة فـي محافظــات دولـة الكويـت الســت و البـالغ

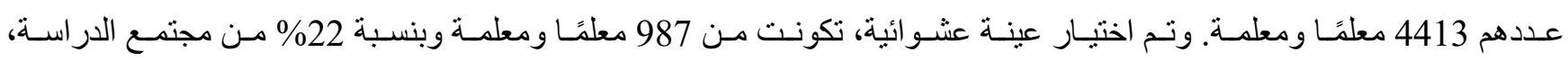

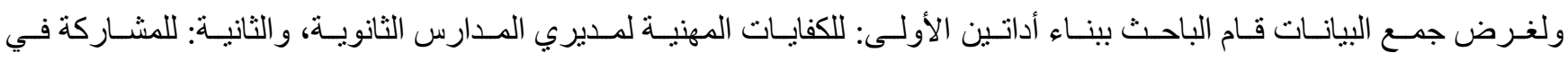

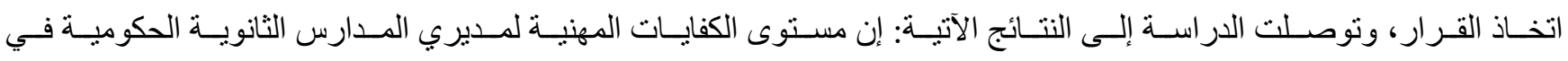

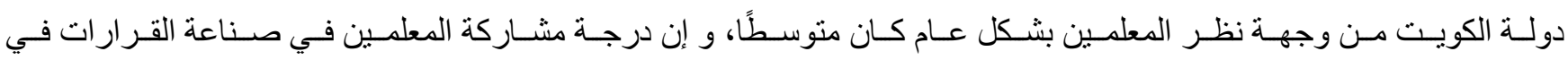

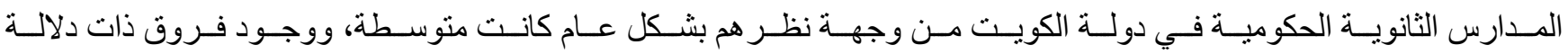

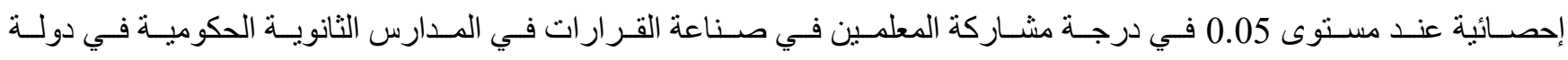
الكويت تبعًا لمتغير الجنس، ولصالح الإناث. التعقيب على الدراسات السابقة:

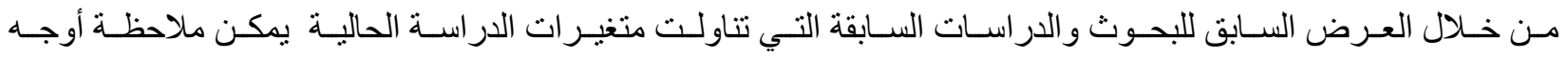
الثبه والاختلاف وما يميز الدراسة الحالية عن الدراسات السابقة ويمكن عرضها كالتالي: أوجه التثابه بين الدراسة الحالية والاراسات والبحوث السابقة:

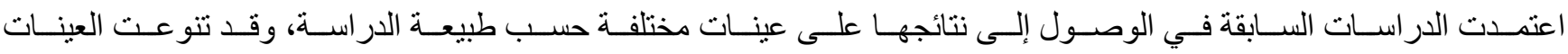
المستخدمة في الدراسات السابقة من حيث العدد و الجنس وطبيعة العينة. ولتحقيـق أهـاف الدر اسـات السـابقة، تتوعـت المنــاهج المسـتخدمة، وتتفق بعض الدراسـات السـابقة مـع الدراسـة الحاليـة في

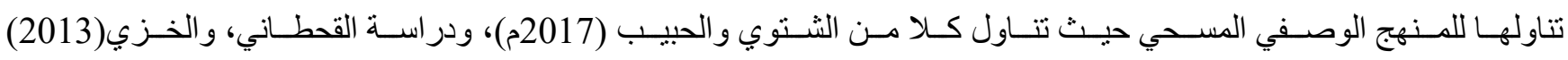
كر اثـي(2015)، ودر اســة الدوسـري(2014)، ودر اســة العتيــي(2008)، ودر اســة (Sonia Bland ford, 2014)، ودر اسة الرميح(1425هـ). كما تنو عت أدوات الدر اسة المستخدمة في الدر اسات السابقة ما بين استبانات ومقاييس جاهزة وأخرى من إعداد الباحثين. 


\section{أوجه الاختلاف بين الاراسة الحالية والدراسات والبحوث السابقة}

تختلـــ الدر اســة الحاليـة عـن الدر اسـات السـابقة بـأن أغلـب الدراسـات اهتمـت بتتميـة الأداء المهنـي ولكـن مـن جو انـب

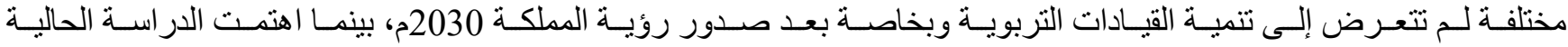
بدر اسة التنمية المهنية للقيادات التربوية في ضوء رؤية المملكة العربية السعودية 2030م. أوجه الاستفادة من البحوث والدراسات السابقة

كـان لهـذه المجموعـة مـن البحـوث و الدر اســات الســابقة أثرهـا فـي توضـيح الرؤيسة أمسام الباحـث فـي جميـع المر احـل،

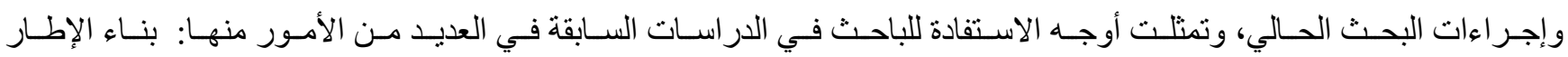

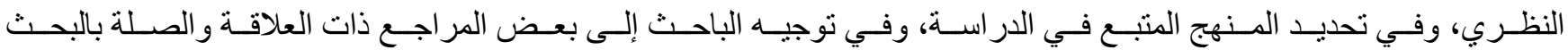
الحالي، وفي تفسير نتائج الدر اسة وتدعيمها بنتائج الدراسات السابقة. منهج الدراسة:

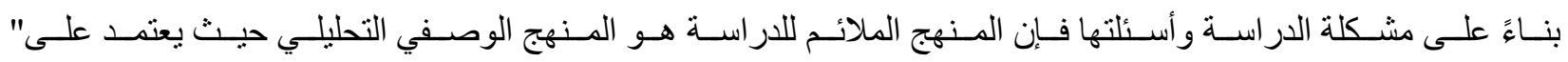

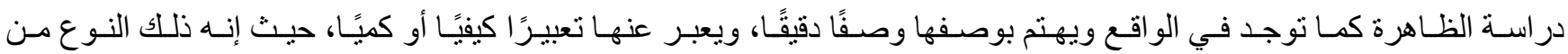
البحـوث الذذي يـتم بو اسـطة اسـتجواب جميـع أفر اد مجتمـع البحـث أو عينـة كبيـرة مـنهم، وذلـك بهـف وصـف الظـاهرة المدروسـة

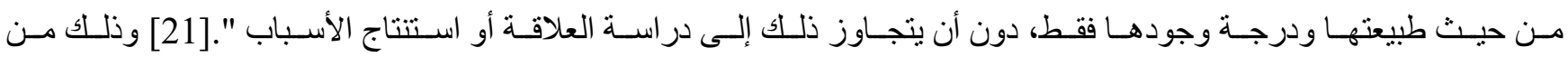

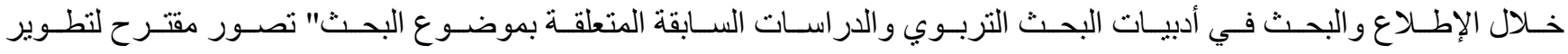
الأداء المهني للقيادات التربوية في ضوء رؤية المملكة العربية السعودية 2030م ". تصور مقترح لتطوير الأداء المهني للقيادات التربوية في ضوء روئية المملكة العربية السعودية 2030م أولا_ منطلقات التصور المقترح: 1 - المنطلق التعليمي للمملكة العربية السعودية:

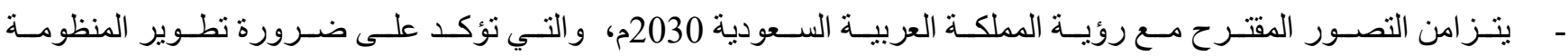

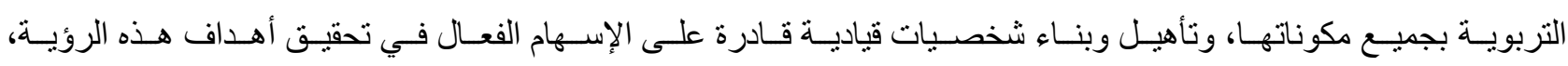
وذلك مو اكبة لرسالة التعليم ودعماً لمسيرتها، لبناء جيل متعلم قادر على تحمل المسؤولية واتخاذ القرارات مستقبلاً.

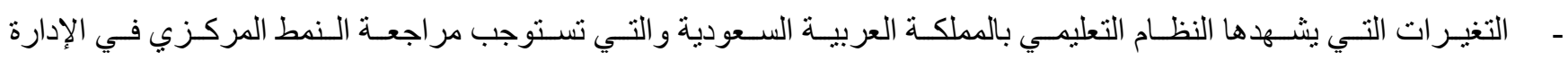
وضعف دوره في تحقيق التطوير المنشود لمنظومة التعليم وتز امن تطويره مع رؤية المملكة 2030م. 


\section{المنطلق السياسي للمملكة العربية السعودية:}

تتمثنل صـورة المجتــع السـعودي السياسـي المتوقـع وفقـاً لمتطلبـات مجتمـع القـرن الحـادي والعشـرين، ورؤيـة المملكـة 2030م فيما يلي:

- مجتمع يؤمن بحرية التعبير عن الر أي و المشاركة السياسية للمو اطن في كافة الأنشطة. - حرص المجتمع السعودي ومؤسساته على الثفافية والنزاهة في كافة الأنشطة. - - إعلاء قيمة العلم و الثقافة في المجتمع السياسي. - توجه المجتمع السعودي نحو إتاحة الفرصة لتمكين المواطن من المشاركة في الحياة السياسية. - وجود قيادات مؤهلة لصنع القرار السياسي، وتقلد مناصب مسؤولة في الدولة. 3. المنطلق الاقتصادي للمملكة العربية السعودية: - وجود خطة للتنمية الاقتصادية والبشرية تحقق منطلبات وطموحات المجتمع السعودي. - ضرورة التحول نحو السوق الوطنية في ظل الأزمة المالية العالمية وتضخم الأسعار. - مجتمع يتجه إلى المنافسة في ظل اقتصاد العولمة وتحرير الأسواق.

- وضع الحكومة سياسات وحو افز لتنجيع القطاع الخاص على المشاركة المتميزة. 4. المنطلق الاجتماعي للمملكة العربية السعودية: - مؤشر ات التنمية في المملكة تشير إلى ضرورة التقدم في المؤشرات الخاصة بالصحة والتعليم. - صياغة منظومة منكاملة من القيم و الأخلاقيات التي تحكم المجتمع. - الاعتر اف بدور مؤسسات المجتمع المدني التي تعمل وفق مرجعية وطنية. - تبني استر اتيجية لتقليص معدل البطالة وصولاً إلى التوظيف الكامل (السعودة). - التوجه المجتمعي نحو تأمين الاحتياجات الأساسية للمو اطنين من غذاء، ومسكن، وموارد مائية، وصحية. 5 5. المنطلق التكنولوجي للمملكة العربية السعودية: - مجتمع علمي تكنولوجي يرتكز إلى اقتصاد المعرفة وتكنولوجيا المعلومات. - - التوجه لإحلال الثقافة العلمية و التكنولوجيه لغة للحوار و التفاهم بين الأجيال الجديدة. - - التوجه من مجتمع مستهلك للتكنولوجيا، إلى مستثمر، ثم منتج لها. - نشر ثقافة التكنولوجيا ومتطلبات بناء مجتمع المعرفة لكافة أوجه الحياة في المملكة. 
ثانيًا _مبررات ومرنكزات التصور المقترح:

- ـ الانفجـار المعرفـي والتطـور التكنولـوجي الـذي يشـهـه العصـر فـرض على القيـادات ضـرورة مواجهـة هـذا التطـور و التغيـر

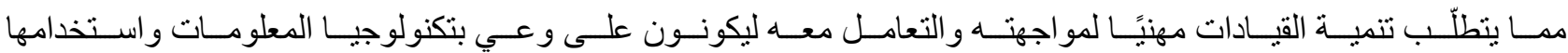
وتوظيفها في عملية القيادة والإدارة داخل المدرسة. - ضـعف ثقافـة التنميـة المهنيـة وضـعف انتثـار ها في المـدارس، فمتابعـة الجديـد في مجـال القبـادة أو الإدارة محسدود للغايـة

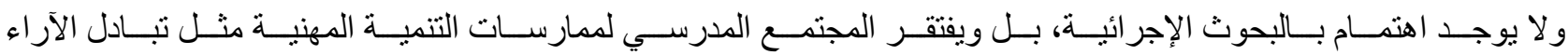
و الزيار ات الصفية والنقد الموضو عي والندوات وورش العمل والتعلّم من المصادر المتنوعة.

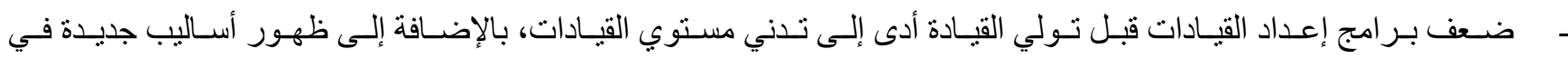

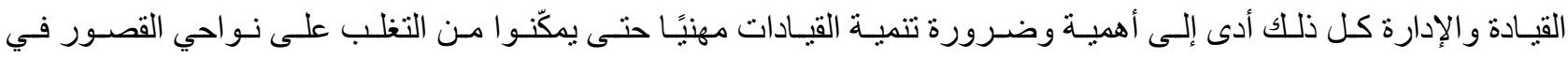
الإعداد ومواجهة التطور ات الحديثة في القيادة والإدارة .

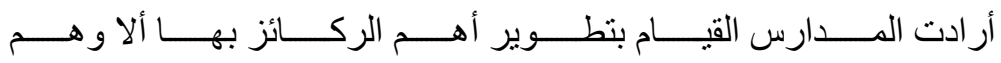
إذا مـ

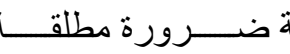

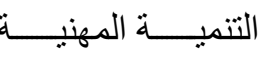
القيادات التربوية. تنميـة قدر ات القيـادات الابتكاريـة وزيـادة قدر اتهم على الإبـداع و التجديـد بمـا يـؤدي إلىى تـر غييهم في المهنـة نتيجـة لنجـاحهم

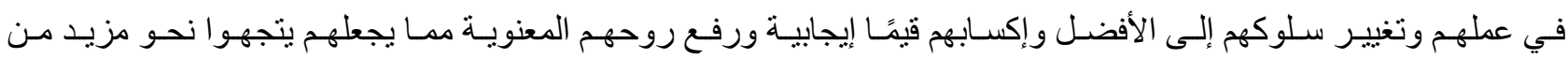
التجديد و التحديث.

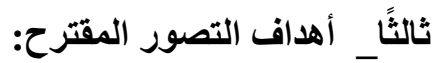
تلافي أوجـه القصـور في إعداد القيـادات قبـل تـولي القيـادة وإعطـاء نـوع مـن التعزيـز لمؤسسـات الإعـداد عن نوعيـة وكفـاءة القيادات الملتحقين بالتدريب حتى يتسنى لها مر اجعة خطط وبر امج الإعداد. - - تحسين جودة أداء جميع القيادات من خلال تنمية مهار اتهم ومساعدتهم على مواجهة منطلبات العمل المتجددة. - رفع معايير الأداء المتوقعة من القيادات التربوية بإز الة وتخفيف بعض المعوقات التي تو اجه القيادات في عمهر. - تمكين القيادات من ممارسة أحدث أساليب القيادة ومن مسايرة التطور التكنولوجي والثورة المعرفية. - مساعدة القيادات على تتمية علاقاتهم الإنسانية وتوثيق الصلة بينهم وبين العاملين معهم البيئة . - - تنمية قدر ات القيادات الابتكارية وزيادة قدر اتهم على الإبداع و التجديد. 


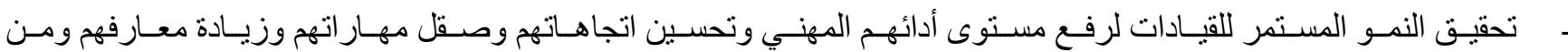
ثم الارتقاء بالمستوى القيادي لهم.

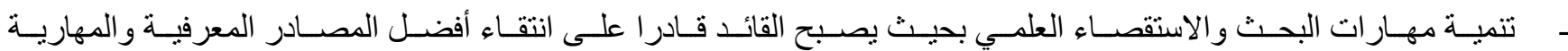
اللازمة و التي تمكنه من القيام بأدو اره المتعددة بفاعلية. تتمية قدرات القيادات على الإلمام بالأساليب الحديثة في القيادة والإدارة وتعزيز خبراته.

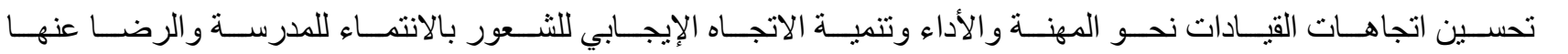
ومساعدتهم على التكيف المهني داخل البيئة المدرسية.

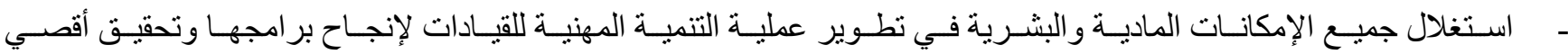
فائدة منشودة من عمليات التنمية المهنية. - التأكيد على مبدأ التنمية المهنية الذاتية للقيادات والعمل التعاوني و العمل بروح الفريق. رابعًا__متطلبات تطبيق التصور المفترح: - وضع خطة محددة الأهداف للتنمية المهنية للقيادات التربوية منو افقة مع رؤية المملكة 2030م . - تو افر المؤشرات الدالة على تحقق أهداف خطة التنمية المهنية للقيادات التربوية والمتو افقة مع رؤية المملكة 2030م. - صياغة خطة التنمية المهنية للقيادات التربوية بناءً على الاحتياجات التدريبية الفعلية. - قيام التخطيط الزمني لبر امج التنمية المهنية على مر اعاة مسؤوليات القادة اليومية. - ربط خطة التنمية المهنية للقيادات التربوية بالخطة الاستر اتيجية لتحسين المدرسة. - أن تسهم بر امج التنمية المهنية في توعية القيادات التربوية بمسؤولياتهم. - التعاون مع كليات التربية في وضع برامج التنمية المهنية للقيادات التربوية وفق رؤية المملكة 2030م . - ت تنفيذ مر اكز التدريب برامج التنمية المهنية وفقا للخطة الموضوعة. - تجهيز قاعدة بيانات متكاملة عن الاحتياجات التدريبية للقيادات المدرسية. تنفذ بر امج التنمية المهنية باستخدام أساليب واستر اتيجيات حديثة قابلة للتطبيق. - تحديد خطط تقييم لبر امج التنمية المهنية للقيادات التربوية تتسم بالموضو عية. - ربط بر امج التنمية المهنية للقيادات التربوية بطبيعة صلاحياتهم الجديدة. - توفر المرونة لبر امج التنمية المهنية حتى يمكن تعديلها حسب الحاجة. 
- توفر حوافز تشجيعية للقيادات التربوية للإلتحاق في برامج التنمية المهنية. - تحديد القيادات التربوية المطلوب تدريبهم ونوع التدريب المطلوب ومدة البر امج و النتائج المتوقعة منهم. خامسا__آليات تنفيذ التصور المقترح: 1. وجـود روئـة واضـــة لبـرامج التنميـة المهنيـة: يجـب أن تعمـل بـر امج التنميـة المهنيـة على أن تكـون رائـدة في تحسـين وتطـوير أداء القيـادات التربويـة، مـن خـلال خطـة مدروســة ترقى بهـم مهنيًا طبقًا للاتجاهـات العالميـة الحديثـة في القيـادة، وبما يضمن تطوير أدائهم وفقًا لمتطلبات التنمية البشرية وضمان الجودة. وجـود رســالة محسدة لبـر امج التنميـة المهنيـة: تسـعى بـر امج التنميـة المهنيـة إلـى بنـاء قـدرات القيـادات التربويـة على

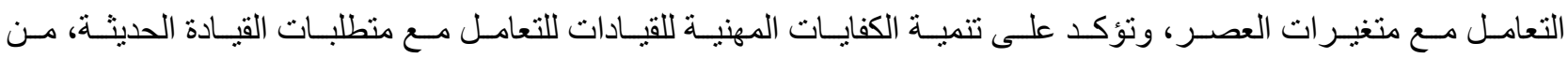
خلال كل ما تقدمه من أنشطة وبر امج تدرييية.

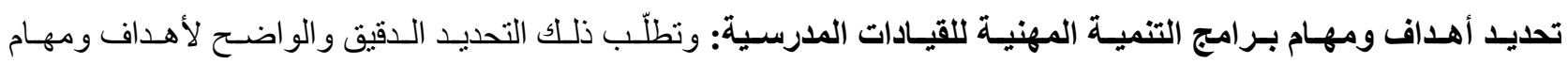
بـر امج التتميـة المهنيـة ومجالاتهـا ووسـائلها فـي ضـوء الو اقـع وتحـديات المسـتقبل، وتعدـل بـر امج التنميـة المهنيـة على تحقيق العديد من الأهداف التي تكون غايتها الأساسية هي تطوير وتحسين أداء القيادات.

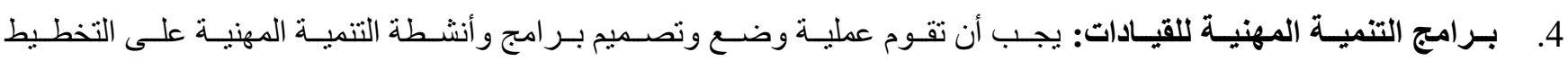

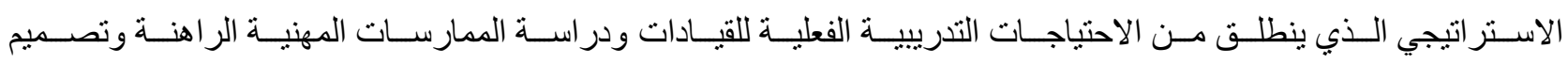

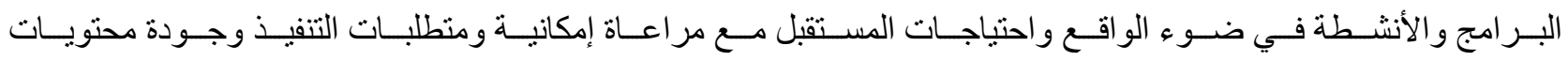

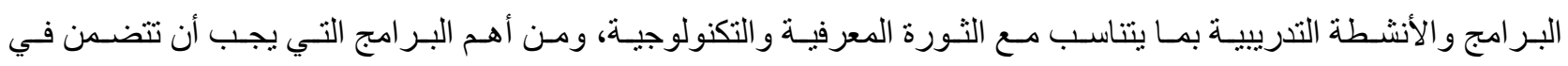
خطة التنمية المهنية للقيادات التربويةما يلي:

$$
\begin{aligned}
& \text { التخطيط الاستر اتيجي والإدارة الإستراتيجية. } \\
& \text { - } \\
& \text { - }
\end{aligned}
$$

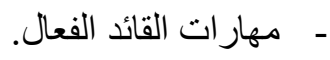

$$
\begin{aligned}
& \text { - - - إدارة الوقت. } \\
& \text { - } \\
& \text { - - مهار ات التو اصل الفعال. }
\end{aligned}
$$


التخطيط الزمنـي لبـرامج التنميـة المهنيـة: يجـب أن يقـوم التخطيط الزمنـي لبـر امج و أنشـطة التنميـة المهنيـة على مر اعـاة

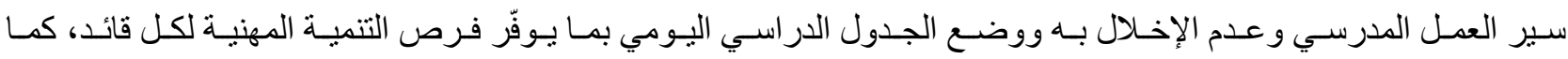

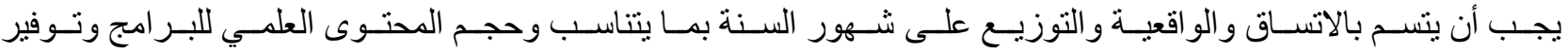
عنصر المرونة الذي يمكن من خلاله إدخال تعديلات على الخطة الزمنية حسب الحاجة.

6. أسـاليب واسـتراتيجيات تنفيـذ خطـة التنميـة المهنيـة: يجـب أن تتســ أسـاليب و اسـتر اتيجيات تتفيـذ بـر امج التتميـة المهنيـة

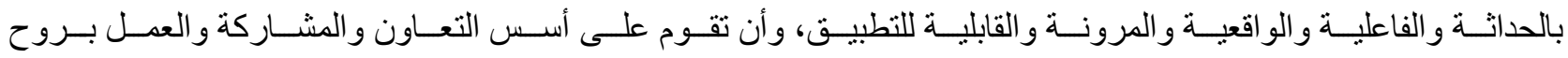

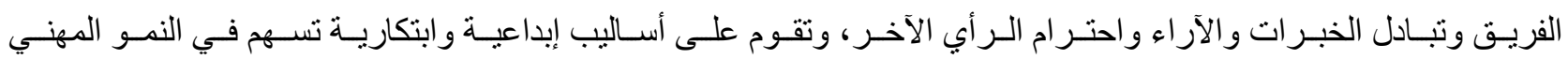
للقيادات المدرسية. تقـويم ومتابعـة بـرامج وأنشــة خطـة التنميـة المهنيـة: ويجـب أن تتســ خطـط التقـويم و المتابعـة بالثــمولية والمرونــة

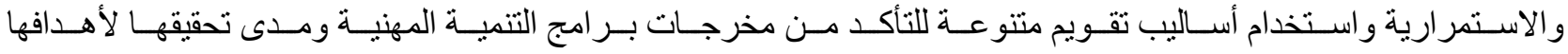

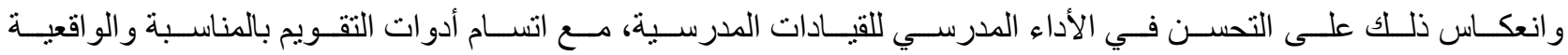
و التكامل. سادسًا _معوقات تنفيذ التصور المقترح:

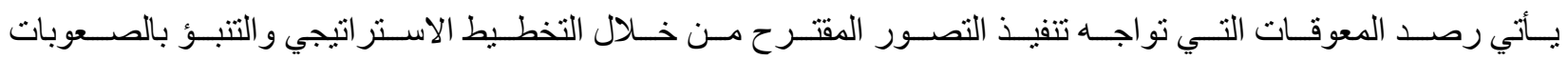

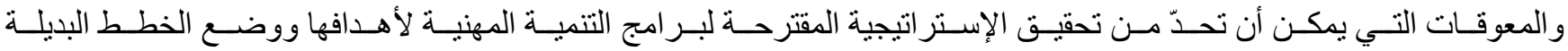
لمو اجهة هذه الصعوبات المنوقعة، وتتمنل أهم المعوقات في:

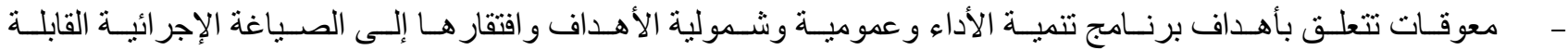
للقياس و التقويم و المفارقة بين أهداف البرنامج التدريبي وبين النظرة المستقبلية.

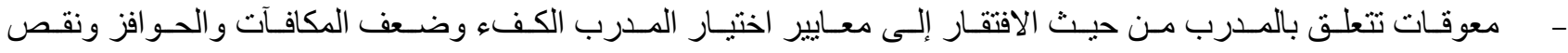
أعداد المدربين المتخصصين. مشـكلات تتعلـق بـالمحتوى التـدريبي وأهمهـا التكـرار فـي معظـم البـر امج التدريبيـة و المفارفـة بـين الأهـداف الموضــعة

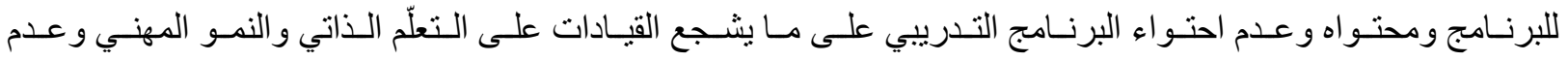
ملائمة الخطة الزمنية المحددة للبرنامج مع محتو اه. 


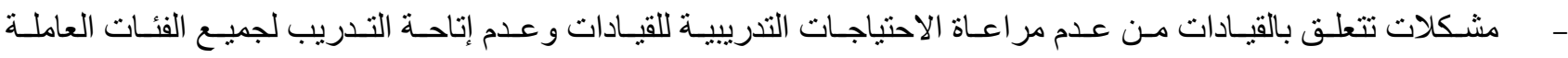

$$
\text { بالتعليم وسلبية المتدرب في اختبار البر امج التدرييية ومحتو اها ومواعيدها. }
$$

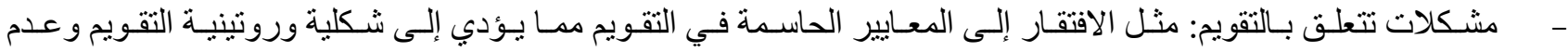

اسـتمر اريته و المجاملــة و التهـاون فـي لجـان التقـويم و عـدم جديـة بحـوث المتـدربين كوسـيلة لتقـويمهم، حبـث يجـب أن

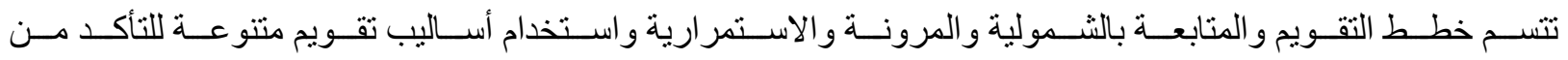
مخرجـات وحـدة التنميـة المهنيـة ومـدى تحقيقهـا لأهـدافها و انعكـاس ذلـك على التحسـن فـي الأداء المدرسـي للمعلمـات ،

$$
\text { مع استخدام أدو ات التقويم المناسبة والو اقعية. }
$$

توصيات الدراسة:

- العمل على وضع خطة محددة الأهداف للتنمية المهنية للقيادات التربوية منو اققة مع رؤية المملكة 2030م .

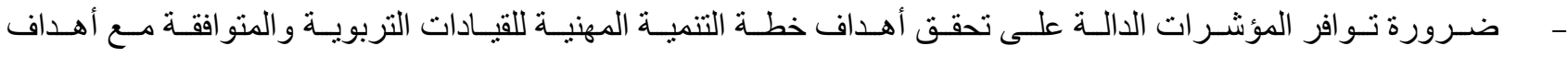

$$
\text { رؤية المملكة 2030م. }
$$

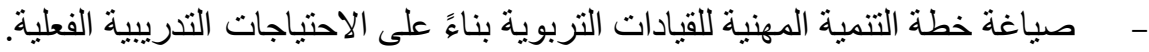

- - قيام التخطيط الزمني لبر امج التنمية المهنية على مر اعاة مسؤوليات القادة اليومية. - التعاون مع كليات التربية في وضع بر امج التنمية المهنية للقيادات التربوية وفق رؤية المملكة 2030م.

ربط خطة التتمية المهنية للقيادات التربوية بالخطة الاستر اتيجية لتحسين المدرسة. - - أن تسهم بر امج التنمية المهنية في توعية القيادات التربوية بمسؤولياتهم. تتفيذ مر اكز التدريب بر امج التنمية المهنية وفقا للخطة الموضوعة. - ـ ـ تجهيز قاعدة بيانات متكاملة عن الاحتياجات التدريبية للقيادات المدرسية. - - توفر حو افز تشجيعية للقيادات التربوية للإلتحاق في بر امج التنمية المهنية. تحديد خطط تقييم لبرامج التنمية المهنية للقيادات التربوية تتسم بالموضو عية. ربط بر امج التنمية المهنية للقيادات التربوية بطبيعة صلاحياتهم الجديدة. ضرورة تو افر المرونة لبر امج التنمية المهنية حتى يمكن تعديلها حسب الحاجة. أن تنفذ بر امج التنمية المهنية باستخدام أساليب واستر اتيجيات حديثة قابلة للتطبيق. أن تسهم بر امج التنمية المهنية في توعية القيادات التربوية بالاتجاهات الحديثة في القيادة المدرسية. 


$$
\begin{aligned}
& \text { - - - مأن نر اعي مر اكز التدريب النظام المدرسي عند تنفيذ بر امج التنمية المهنية للقيادات المدرسية. } \\
& \text { أن تشنمل خطط تنفيذ بر امج التنمية المهنية للقيادات التربوية على أساليب تقويمية لقياس تأثير نتائج التدريب . } \\
& \text { - - أن تسهم بر امج التنمية المهنية في زيادة قدرة القيادات التربوية على صنع القرار. } \\
& \text { - - أن تسهم بر امج التنمية المهنية في تطوير قدرة القيادات التربوية على مو اجهة الأزمات المدرسية. } \\
& \text { - - إعطاء حو افز وميزات مالية للعاملين في مجال القيادة المدرسية . }
\end{aligned}
$$

- أن تنفذ إدارات التعليم الخطة السنوية للتنمية المهنية للقيادات التربوية بشكل دقيق.

- - أن تركز بر امج التنمية المهنية على الجانبين النظري والفني أثناء التدريب .

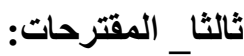

انطلاقــاً مــن أهميــة موضــوع تتميــة الأداء المهنــي ودوره المهـم فـي الارتقــاء بالمسـتوى المهنــي للقبـادات التربويسة،

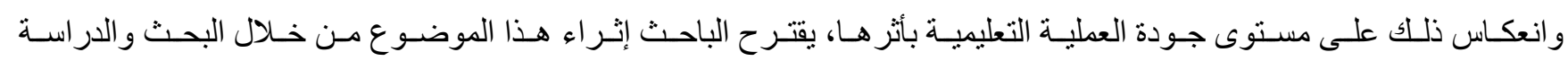

من خلال المقترحات التالية:

- إجر اء در اسة ميدانية حول تقييم نتائج بر امج التنمية المهنية المقدمة للقيادات التربوية في مجال القيادة.

- - در اسة فاعلية بر امج التنمية المهنية في رفع كفاءة استخدام التكنولوجيا لدى القيادات التربوية. - - مر اسة دور مر اكز التدريب في النمو المهني للقيادات التربوية بالمملكة في ضو ء رؤية 2030م.

- دراسة دور إدارات التعليم في تحقيق النمو المهني للقيادات التربوية في مجال القيادة. - در اسة تقييمية لجودة بر امج التنمية المهنية للقيادات التربوية في مجال القيادة. 
قائمة المصادر والمراجع:

[1] الطاهر، رشيدة السيدة أحمد. التنمية المهنية للمعلمين في ضوء الاتجاهات العالمية تحديات وطموحات. القاهرة: دار الجامعة

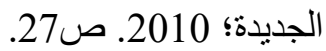

[2] الثمري، مشعان بن ضيف الله بن مقبل. تطوير برامج التنمية المهنية لقادة المدارس بالمملكة العربية السعودية في ضوء

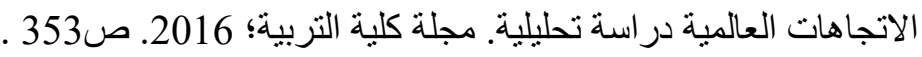

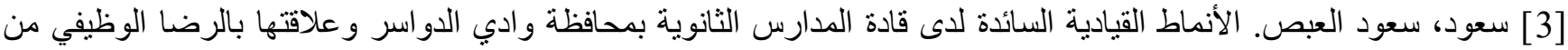
وجهة نظر المعلمين. رسالة ماجستير غير منشورة. كلية العلوم الاجتماعية: جامعة الإمام محمد بن سعود الإسلامية؛ 2017.

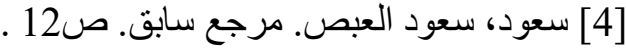

[5] Jiang Binbin. et all. The Effectiveness of an Embedded Approach to Practicum Experiences in Educational Leadership: Program Candidates' Perspectives : International Journal of Teaching and Learning in Higher Education, 25 (1); 2013. p79-91.

[6] Jonathan. School Leadership Lessons from England. Phi Delta Kappan, 97 (3); 2015. P39.

[7] Grootenboer Peter; Hardy. Contextualizing, Orchestrating and Learning for Leading: The Praxis and Particularity of Educational Leadership Practices, Educational Management Administration \& Leadership. 45 (3); 2017. p402.

[8] طيب، عزيزة عبد الله؛ الوشمي، أسماء ناصر ابر اهيم. ممارسة المهار ات القيادية لدى مديرات المدارس المطبقة للبرنامج الوطني

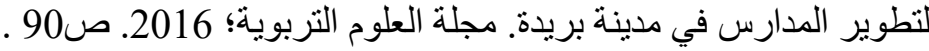

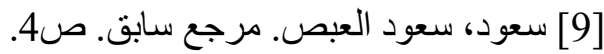

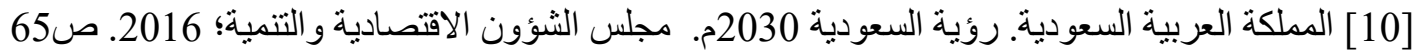

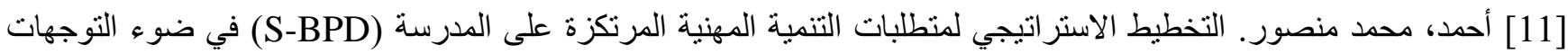

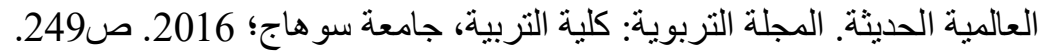

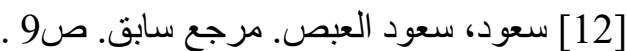

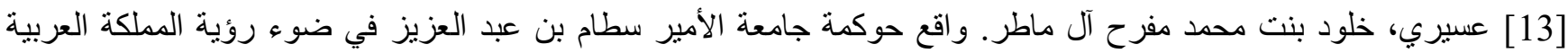
السعودية 2030 من وجهة نظر القيادات الإدارية والأكاديمية فيها. رسالة ماجستير غير منشورة: كلية التربية، جامعة الأمير سطام؛ 2017. صن.10. [14] محمد، نسرين؛ عبد النعيم، منال. برنامج إرشادي للتنمية المهنية المستدامة للمعلمين في ضوء تباينات مسار اتهم المهنية: تصور

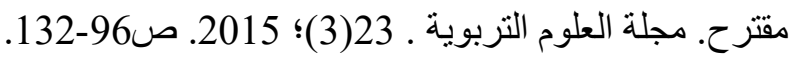

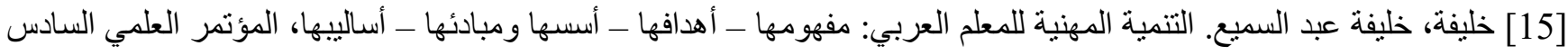
(التنمية المهنية المستديمة للمعلم العربي) الفترة من 23-24 أبريل. كلية التربية. فرعة الفيدة الفيوم. جامعة الفئة القاهرة؛ 2012.

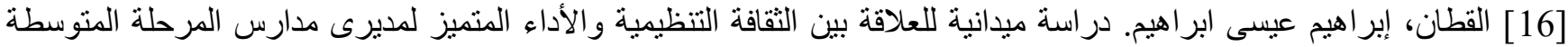
بدولة الكويت. رسالة ماجستير غير منشورة. كلية التربية. جامعة بنها؛ [17] Hussin Sufean; Al Abri. Professional Development Needs of School Principals in the Context of Educational Reform. International Journal of Educational Administration and Policy Studies, 7 (4) ; 2015 . 92.

[18] عزت، منتهى جودت. نطوير نظام التنمية المهنية لمديري المدارس الثانوية العامة بالضفة الغربية في ضوء منطلبات الاحتر اف.

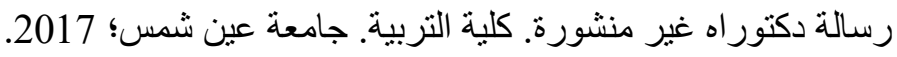

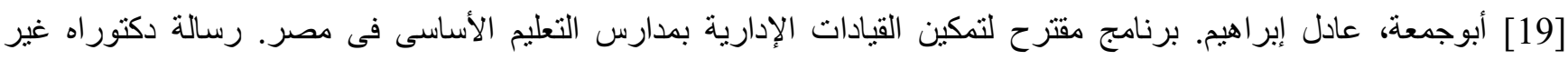

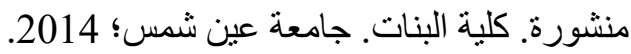

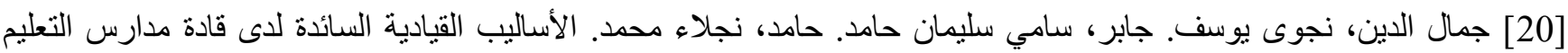

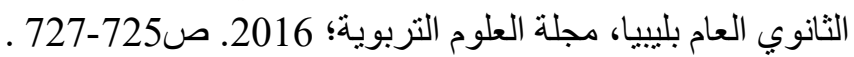
[21] العساف ، صالح محمد ـ المدخل إلى البحث في العلوم السلوكية ـ ط2 ـ الرياض : دار الز هر اءه ؛ 2012م . 